\title{
WestVirginiaUniversity
}

THE RESEARCH REPOSITORY @ WVU

Graduate Theses, Dissertations, and Problem Reports

2012

\section{Eurasianist Trends in Russian Foreign Policy: A Critical Analysis}

Steven K. Voytek

West Virginia University

Follow this and additional works at: https://researchrepository.wvu.edu/etd

\section{Recommended Citation}

Voytek, Steven K., "Eurasianist Trends in Russian Foreign Policy: A Critical Analysis" (2012). Graduate Theses, Dissertations, and Problem Reports. 256.

https://researchrepository.wvu.edu/etd/256

This Thesis is protected by copyright and/or related rights. It has been brought to you by the The Research Repository @ WVU with permission from the rights-holder(s). You are free to use this Thesis in any way that is permitted by the copyright and related rights legislation that applies to your use. For other uses you must obtain permission from the rights-holder(s) directly, unless additional rights are indicated by a Creative Commons license in the record and/ or on the work itself. This Thesis has been accepted for inclusion in WVU Graduate Theses, Dissertations, and Problem Reports collection by an authorized administrator of The Research Repository @ WVU. For more information, please contact researchrepository@mail.wvu.edu. 
Eurasianist Trends in Russian Foreign Policy: A Critical Analysis

Steven K. Voytek

Thesis submitted to Eberly College of Arts and Sciences at West Virginia University in partial fulfillment of the requirements for the degree of

Master of Arts in History

Robert Blobaum, Ph.D., Chair Joshua Arthurs, Ph.D. Elizabeth Fones-Wolf, Ph.D.

Department of History

Morgantown, West Virginia 2012

Keywords: Russia; Foreign Policy; Eurasianism

Copyright 2012 Steven K. Voytek 


\section{ABSTRACT \\ Eurasianist Trends in Russian Foreign Policy: A Critical Analysis \\ Steven K. Voytek}

This paper examines and illustrates the presence of a powerful Eurasianist doctrine currently informing Russian foreign policy. It first presents the historical evolution of Eurasianism, its most recent incarnation present in contemporary Russia, and later seeks to explicate its development. The emergence of this particular doctrine was the result of a gradual process that began in 2000 when Vladimir Putin first became President of the Russian Federation although its historical roots are traced back to the $19^{\text {th }}$ century. Over the course of the past decade a new brand of Eurasianism has emerged which this study identifies as 'Geopolitical Eurasianism'. Various external and internal factors have led to the rise of this paradigm which now dominates the formulation and implementation of Russian foreign policy. Ultimately Geopolitical Eurasianism is shown to be the principle doctrine guiding Russian foreign policy over the past decade and demonstrates that Russia will most likely continue on this current trajectory. 
Funding for my thesis and my MA studies at West Virginia University, Collegium Civitas, and the University of Tartu was made possible by the Transatlantic MA Program in EastCentral European Studies, an "Atlantis" project sponsored by the Fund for the Improvement of Secondary Education of the U.S. Department of Education and the European

Commission's Executive Agency for Education, Audiovisual and Culture. 


\section{Table of Contents}

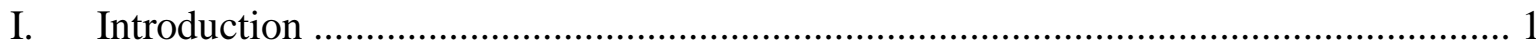

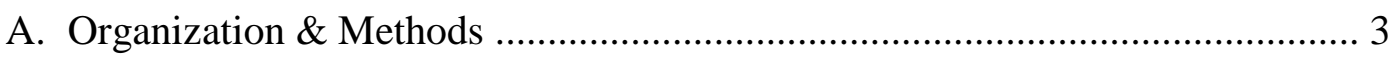

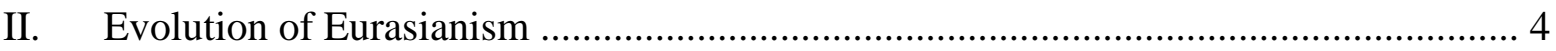

A. The Roots of Early Eurasianism: Slavophilism ............................................. 6

B. The Russian Émigré Community \& Classical Eurasianism ........................... 11

C. The Re-emergence of Eurasianism: Neo-Eurasianism ................................ 16

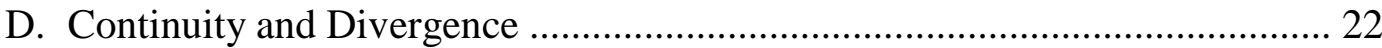

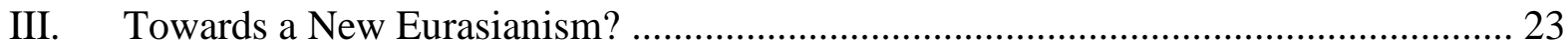

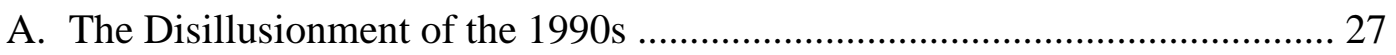

B. Early Stages of Putin's Presidency ............................................................. 31

C. Medvedev: A New Foreign Policy Concept? ............................................... 40

D. The 2008 Russo-Georgian War: Flexing Eurasianist Muscles ....................... 42

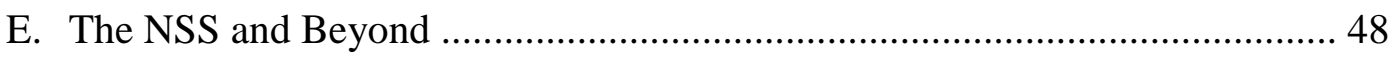

F. The Eurasian Union: Culmination of Geopolitical Eurasianism ................... 51

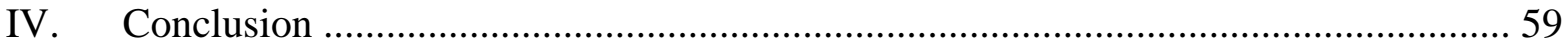

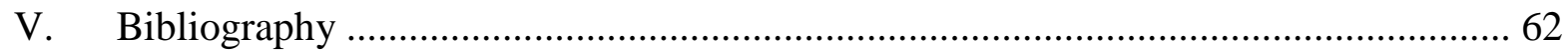




\section{Introduction}

The Russian Federation has undergone an extended period of transition since the collapse of the Soviet Union in the early 1990s. It has seen dramatic transformations take place in many of its core institutions - institutions that were simultaneously created and later changed to fit the nebulous definition of what should constitute a modern-day 'Russia'. This question has always been the foundation for any academic inquiry into Russia- who and what truly constitute Russia and its people? This perennial debate has stymied policy makers and researchers alike. Addressing this question is therefore of critical importance to understanding not only contemporary Russia, but to also make good policy in regards to it. Every institution in Russia is informed by how its government and people see themselves fitting into the international power structure. This is perhaps most evident with how its foreign policy is not only carried out, but also how it is articulated and formulated from within. Over the past twelve years Vladimir Putin has risen from relative obscurity to Presidency. His accession, along with multiple other shifts in international and domestic realties, has fundamentally transformed the type of foreign policy Russia puts into practice.

Yet, widespread disagreement materializes when one tries to categorize specifically the type of foreign policy Russia seeks to implement. Historically, Russia has oscillated between two broadly defined factions_- 'atlanticists' and 'eurasianists'. These two groups have traditionally encompassed the largest swath of foreign policy thinking in modern Russia. Since 1992 Russia has undergone a number of shifts between these two camps. However, since 2000 Russia has undertaken a longer term trend towards the latter. This reshaping is a mixture of many iterations of Eurasianism throughout its history. This combination can best be described as 'geopolitical Eurasianism'- a new doctrine that most informs Russian foreign policy. This distinctive type of Eurasianism has had and will continue to have lasting implications on Russian foreign policy for the foreseeable future. ${ }^{1}$ It is therefore important to understand this phenomenon. The reasons are twofold. First, good policy can only be made if one's underlying assumptions are based on a good understanding of the real world. Thus, a better understanding of the character of Russian foreign policy informs good policy elsewhere. Second, a critical appraisal of Russian foreign policy contributes to the broader study of international relations and post-Soviet studies insofar as it deepens the field's

\footnotetext{
${ }^{1}$ For the sake of clarity and brevity, this mixture will simply be referred to as Eurasianism for the rest of this study, although the two are not entirely interchangeable. If a clear distinction needs to be made, the full term 'geopolitical Eurasianism' will be used to make a differentiation.
} 
understanding of a very influential actor within both disciplines. Clearly the importance of an in-depth analysis of Russian foreign policy cannot be understated.

It is the contention of this thesis that the Russian Federation, especially since Putin's rise to power, has shifted its diplomatic efforts away from collaboration with the transatlantic powers who compose the West and towards areas and regions which are distinctly nonWestern. Simultaneously, Russia has sought to reinforce the idea of 'multipolarity' in the international system by opposing the United States and its allies on a variety of issues in an effort to undermine what they perceive to be a 'unipolar' system. In response to changing demographic realities, as well as a need for a more cohesive national identity, the Russian leadership has increasingly embraced a conception of Russian statehood which traces its roots to the development of Eurasianism. Taken together, these developments constitute a wholly new brand of Eurasianism, which this study terms 'Geopolitical Eurasianism.' Such decisions were pragmatic in nature and done to better address changing political, economic, and domestic realities. These changing realities will later be shown to be a main impetus for this shift in foreign policy thinking. The changes taking place in these areas represent an intersection between geopolitics and the creation of national 'Russian' identity. Thus, both external and internal pressures have led to this shift in policy. The power of ideational factors, in concert with external constraints, can and will be shown to have exerted tremendous influence over Russian foreign policy decision making. Only in combination could this have been possible. Consequently, this dichotomy provides the necessary theoretical foundation to the policy choices carried out by the Russian Federation.

To this end it is the aim of this paper to critically assess and analyze Russian foreign policy from the beginning of Putin's presidency in 2000 up through his third term recently begun in May of 2012. This study will evaluate the Russian Federation's actions over the past twelve years in connection to the formulation and implementation of its foreign policy. During this process a more accurate characterization of its diplomacy will emerge. A sustained Eurasianist pattern will be established as the prevailing doctrine among many competing for influence in determining Russian foreign policy. In addition to such an analysis, it will also be the aim of this paper to more accurately predict the trajectory of Russia's foreign policy in the short to medium term. The range of these forecasts are constrained both by the relatively small scope of this study and also by recent upheavals in domestic Russian politics, most notably the street protests in Moscow and St. Petersburg. Yet, the Eurasianist drift since Putin's ascendancy still provides ample evidence to make more modest forecasts going forward. 


\section{Organization \& Methodology}

The organization of this paper will be as follows. The first section of this study will outline the history surrounding Eurasianism, its place in the larger Russian foreign policy discourse, and its contemporary proponents and interpretations. Next, an analysis section will follow illustrating specifically what the Russian Federation has done to constitute a reevaluation of how to typify its diplomatic efforts. This analysis will draw evidentiary support from the period of 2000 through 2012 highlighting specific actions and policies the state has put into effect that reorient its foreign policy in a Eurasianist fashion. The final section will summarize and draw conclusions from the previous sections. Additionally, its intended trajectory will also be evaluated for the short term.

This study will employ a qualitative content analysis approach. It will investigate a number of primary source materials to demonstrate the nature of Russian foreign policy. These will come in the form of governmental publications, Russian official's public statements, and domestic reportage among other things. From these varied sources evidence will be drawn to support the hypothesis that Russian foreign policy is inexorably moving towards a more Eurasianist posture. Moreover, secondary source material will be utilized to illustrate the current state of debate over how best to categorize the nature of Russia's contemporary diplomatic efforts. Eurasianist terminology, its related geopolitical logic, and even overt references to a more Eurasianist position, among other substantiations, will be shown to be present in all source materials. Clear and tangible evidence will thus be drawn from both types of sources to demonstrate this shift.

While this paper is not a singular case study in and of itself, it will still employ a series of smaller cases that exemplify a larger geopolitical Eurasianist pattern in the Russian Federation's foreign policy. The salience of these case studies will be made evident as they are used during the content analysis. Moreover, they were selected not only because of their significance to this hypothesis, but also because of their overall importance in a larger historical context. Case studies compliment content analysis research best because they are useful in demonstrating the specific causal relationships, inherently present in the international system, which lead states to implement specific policies. It illustrates these relationships in a way that synthesizes an enormous amount of variability and complexity into a more tractable structure for evidentiary support. Furthermore, many examples were chosen for this study instead of just one. Assigning vast importance to a singular event and attributing an exclusive causal relationship with this hypothesis would not clearly demonstrate a pattern over a set period of time. Obviously certain cases will rank higher in importance than others, 
but it is the development of an overall trend that is most important to this work. Thus, when particular cases are used, the causal processes at work can be immediately related back to a larger Eurasianist pattern.

\section{Evolution of Eurasianism: Continuity and Divergence}

Eurasianism, as a concept, is a rather nebulous term especially within the context of Russian foreign policy. It means many things, to many different groups of people. The concept itself has undergone many transformations since its inception and has also been variously interpreted by many different groups. At its core it is a political ideology based on the idea that Russia inhabits a unique geographical place between Europe and Asia. It is therefore neither Europe nor Asia. Instead it constitutes a singular political space simply known as Eurasia. This idea is largely borne out of the contention that Russia "never seemed completely European to the Europeans, and although most of its territory was in Asia, it was never completely Asian to the Asians." It is this unique mixture of Europe, fused with its historical ties to Asia, that have led Russian Eurasianists of all stripes at the very least to embrace collectively this type of national identity. This national identity in turn is what informs foreign policy decision making at a most fundamental level. Eurasianists therefore filter all of their political and strategic thinking through this ideological prism. While the motivations for doing so diverge considerably, this is the strongest, if albeit tenuous link, between all iterations of Eurasianism. It is this ambiguous Eurasian identity that justifies the many conceptualizations of Eurasianism that have been espoused over the past two centuries by various groups and individuals.

Yet, the importance of place cannot be understated. As Marlène Laruelle, one of the foremost scholars on the subject asserts, "It rejects the view that Russia is on the periphery of Europe, and on the contrary interprets the country's geographic location as grounds for choosing a messianic 'third way'."3 This so-called 'third way' is the justification for Russia to pursue alternative routes to becoming an independent power pole in the international system. This had been a recurrent theme in the Slavophile tradition of the mid- $19^{\text {th }}$ century, in the classical Eurasianism of the 1920s, and also in its more contemporary form which is the primary subject of this study. Accordingly, Russia should derive its standing in the

\footnotetext{
${ }^{2}$ Peggy Heller, "The Russian Dawn: How Russia Contributed to the Emergence of 'the West' as a Concept," in The Struggle for the West: A Divided and Contested Legacy, eds. Christopher Browner \& Marko Lehti, 33-52 (London, UK: Routledge Press, 2009), 34.

${ }^{3}$ Marlène Laruelle, Russian Eurasianism: An Ideology of an Empire, trans. Mischa Gabowitsch (Washington, D.C.: Woodrow Wilson Center Press, 2008), 1.
} 
international system from the perceived importance of the Eurasian landmass - an idea that was a central contention of Halford Mackinder's 'Heartland Theory' which argued that whatever political entity controlled the Eurasian landmass, or the 'great pivot', would be destined to be the most powerful actor in the international system. ${ }^{4}$ Clearly geopolitical considerations, in their rawest form, were a common element throughout all stages of Eurasianism's development. The salience of geographical location was not only foundational. It was also widely regarded as a science among many Eurasianists who argued it was not simply a theory, but also an objective epistemology. ${ }^{5}$ Thus, Russian intellectuals and policymakers who have embraced Eurasianism have done so mainly to try and articulate their state's national character in the context of geopolitics and national identity. In doing so Eurasianists seek to articulate objectively the most important national interests for Russiaan indispensable component to creating good policy.

Eurasianism is best understood as an attempt to preserve Russian heritage throughout a vast empire stretching over two continents. Yet, it also was the raison d'etre for its global political ambitions which can be traced to Russia's imperial past. As one scholar put it Eurasianism "simply stresses Russia's uniqueness and argues that Russia need not Westernize in order to modernize. But in its hard-line version, the movement envisions the Eurasian heartland as the geographic launch pad for a global anti-Western movement ..."6 These contending lines of rationalization are two very important threads to understanding the overall nature and character of Eurasianism throughout its existence. They have alternatively been used together and separately to justify Eurasianist ideology. At times the idea of Eurasianism has been used to maintain national unity among an extremely diverse population. Thus, Eurasianism has been used as a means of validation for Russia's multiethnic character. This same argument can also be understood as a rejection of perceived Western cultural superiority. Instead Eurasianists sought to emphasize the value of Russia's unique cultural heritage and historical legacy. In essence Eurasianism can be viewed as a vehement rejection of an increasingly globalized world. On the other hand, and most important to this study,

\footnotetext{
${ }^{4}$ Halford J. Mackinder, "The Geographical Pivot of History," The Geographical Journal 23 (April 1904): 421437. It should be noted at this juncture that the viability of Mackinder's thesis will not be evaluated. His hypothesis is important to this study insofar as it influenced many Eurasianists, past and present, leading them to focus much of their attention on geopolitical considerations. For a contemporary analysis of Mackinder's Heartland Theory see: Anita Sengupta, Heartlands of Eurasia: The Geopolitics of Political Space, (Lanham, MD: Lexington Books, 2009).

${ }^{5}$ Ryszard Paradowski, Liliana Wysocka, and Douglas Morren, “The Eurasian Idea and Leo Gumilëv's Scientific Ideology," Canadian Slavonic Papers 41 (March 1999): 25.

${ }^{6}$ Charles Clover, "Dreams of the Eurasian Heartland: The Reemergence of Geopolitics," Foreign Affairs 78 (March - April 1999): 9.
} 
Eurasianism has been used to justify Russia's great power status, especially in the face of massive internal as well as external sociopolitical and economic upheavals. It is this continued great power status that Eurasianists seek to preserve, especially by opposing the West as validation for its significance within the international system.

Obviously, it is quite difficult to offer a singular definition of Eurasianism. For all the continuity seemingly present in Eurasianism as a whole, there are still many widely divergent interpretations. Generally speaking the development of Eurasianism can be placed into three major transformative periods: the mid- $19^{\text {th }}$ century Slavophile movement, the articulation of classical Eurasianism in the 1920s, and the post-Soviet period. While some commonalities are characteristic of all three periods, they continue to differ in how they each relate to the type of Eurasianism present in contemporary Russian foreign policy. The reasons for this will become clear further in this chapter. However, the main explanation for this variance is largely due to the historical context in which they were each first formulated. Major social, political, and economic upheavals have characterized much of Russian history. Events such as the January Uprising in the Polish-Lithuanian Commonwealth, the Russian Revolution of 1917, and most relevant to this study the ultimate collapse of the Soviet Union all had a significant impact on how Eurasianism came to be understood. Clearly the concept was not created in a vacuumit was the result of not only a political and academic need to better define Russian identity so as to create better policy, but also as a reaction to massive historical events and transformations taking place during the same time.

\section{The Roots of Early Eurasianism: Slavophilism}

Much of the existing literature on Eurasianism simply begins with its most overt emergence within 1920s émigré circles. It often ignores, or largely minimizes, the importance Slavophilism had on the eventual creation of Eurasianism. Thus, this chapter seeks to demonstrate and emphasize a strong historical link between the Slavophile movement of the mid $19^{\text {th }}$ century and classical Eurasianism of the 1920s. Only then can a full account of its modern iterations be placed in a proper historical trajectory. Mainly during the 1830 s to 1850s, the Russian Empire was seeking to answer a fundamental question: Is Russia truly a part of Europe or is it something wholly different? This seminal debate was framed for much of this time between 'Slavophilism' and 'Westernism' and would have lasting implications on how Russians identified themselves and also how they viewed their place in the international system. Much like 'Atlanticists' and 'Eurasianists', these contending factions were present among the Russian political and intellectual elite. They intensely deliberated on whether to go 
through the 'window to the Western world' that Peter the Great had opened during his time as Tsar or to pursue an alternative path emphasizing the unique civilization of the Russian Empire. Slavophilism, the more dominate of the factions during this period, was, “. . an expression of an identity crisis within the educated elite, which was due to certain social and political developments in late eighteenth- and early nineteenth-century Russia."7 Clearly, a more precise definition of what truly constituted 'Russia' was needed.

The brothers Pyotr and Ivan Kireyevsky, Aleksey Khomyakov, Ivan Aksakov, and Yuri Samarin are generally considered to be the founders and main leaders of Slavophilism. ${ }^{8}$ These men were prominent Slavophiles who were highly influential in founding as well as leading the movement. Geoffrey Hosking, a renowned Russian historian, sums up Slavophilism's main contention that Russia was not very European, but instead possessed, “. . . its own distinctive political system, which is based on autocracy and the Orthodox Church . . ." and also contended that, “. . . Russia is an empire, it's not a nation-state. And it shouldn't try to become one, because half of its population is non-Russian." ${ }^{9}$ These are the core pillars of Slavophilism that informed the concept. It fundamentally rejected the notion that Russia had to 'Westernize in order to modernize' - a rejection that became one of the central tenets of Eurasianism according to Clover. It advocated for a strong centralized authority that was deferential to the Orthodox faith. As one delves deeper into Slavophilism then, it becomes readily apparent that many of the core ideas underpinning much of Eurasianism were first espoused by many Slavophiles during this period. It is therefore vital to trace its origins to this period.

Interest in Slavophilism was spurred to a great extent by increased Russian interaction with Western European powers. These dealings emphasized the disparities between Russia and the West and stoked feelings of inferiority towards their European neighbors. This feeling was perhaps best encapsulated by the Russian intellectual Pyotr Chaadayev, who while not an overt Slavophile himself, nonetheless was an important figure in framing the SlavophileWesternist dispute. "We do not belong - Chaadayev writes - either to the West or to the East,

\footnotetext{
${ }^{7}$ Susanna Rabow-Edling, Slavophile Thought and the Politics of Cultural Nationalism (Albany, NY: State University of New York Press, 2006), 22.

${ }^{8}$ Frank Fadner, Seventy years of Pan-Slavism in Russia: Karazin to Danilevskiu: 1800-1870, (Washington, D.C.: Georgetown University Press, 1962); See also Nicholas Riasanovsky, Russia and the West in the Teaching of the Slavophiles (Cambridge, MA 1952); Peter Christoff, Introduction to Nineteenth-Century Russian Slavophilism, 4 vols. (Boulder, CO: Westview Press, 1961-91); Andrzej Walicki, A History of Russian Thought from the Enlightenment to Marxism (Stanford, CA: Stanford University Press, 1979), 92-93.

${ }^{9}$ Geoffrey Hosking, "Slavophiles and Westernizers in Russia," interview by Valdai Discussion Club, March 21, 2012, <http://valdaiclub.com/politics/40240.html>.
} 
and we do not possess the traditions of the one, or the other." ${ }^{10}$ Structuring the debate in such a fashion clearly resonates with Eurasianists espousing similar views in the 1920s and beyond. Chaadayev reinforced the importance of defining Russian national identity — an identity that at least both groups agreed was wholly different than that of Europe or Asia. Accordingly, while the two camps may have disagreed on the path Russia should take moving forward, they both agreed that Russia was different than Western Europe. Their differences resided in how they viewed this separateness.

The Westernists viewed Russia's differences with Western Europe in a highly negative fashion. They advocated for Russia to westernize itself in an effort to modernize and to also develop closer ties with the European power structure. They viewed Western Europe as the only viable route to economic and political modernization and they embraced the legacy of Peter the Great. Conversely, Slavophiles argued that they should go in a different direction entirely, not modeled on any existing 'civilization', but instead create a Slavic alternative. Without a doubt, this debate was steeped in Eurasianist ideas and logic even if it historically preceded the most overt appearance of the concept itself. Slavophiles made many of the same arguments regarding Europe and Russia that the classical Eurasianists of the 1920s and neo-Eurasianists of post-Soviet Russia would later make. They centered on two core principles that are a recurrent theme throughout Eurasianism's history- emphasis and idealization of Russia's unique civilization and cultural heritage and a stoic opposition to the 'West' as a foundation for Russia's great power status.

During the period of the 1830 s to 1850 s Slavophiles had ample opportunity to compare Russia's economic, social, and political conditions to those of Western Europe. In doing so this educated elite recognized the relative backwardness of their economy. Institutions such as Serfdom — still in existence until 1861 — reinforced the notion that Russia was somehow not a part of European culture and tradition. Especially in the realm of war Russians were exposed to the more sophisticated militaries of the West during the country's defeat in Crimea and prior to that in its participation in the victory over Napoleon. Exposure to the advanced militaries and societies of Western Europe resonated deeply within the intellectual community in Russia. Clearly Russia's achievements abroad were not matched by the domestic conditions at home. It was clear that reform was needed. Yet, how could reforms take place without subsuming Slavic culture to that of the West - a region that despite its advanced social, economic, and technological prowess still needed to be saved from Napoleon

\footnotetext{
${ }^{10}$ Pyotr Chaadayev cited by Janusz Dobieszewski, "Pëtr Chaadaev and the Rise of Modern Russian Philosophy," Studies in East European Thought 54 (March 2002): 33.
} 
by a clearly technologically, economically, and socio-politically inferior state? Slavophilism was the obvious answer to this need - a strong belief in the primacy of Slavic culture and tradition as a direct repudiation of Western European influence.

Slavophiles, especially Ivan Kireyevsky, rejected the Western embrace of rationalism and instead argued that Russian Orthodox culture embodied a superior moral dimension of understanding. It would take the necessary technologies and practices from the West, but preserve its Slavic Orthodox culture in the process. Slavophiles argued that the West, while seemingly more advanced in the material world, lagged behind Orthodox culture spiritually. The prominent Slavophile Stepan Shevyrev, editor of the Slavophile periodical Moskvitianin (The Muscovite), intensely wrote in 1841 that, "In our relations with the West . . . we are dealing with a man suffering with a malignant and contagious disease, and exhaling a deadly breath . . . associating with him so freely we do not notice the concealed poison . . . we do not perceive the future corpse of which he already smells."11 Slavophilism was thus firm in the belief that the Orthodox faith, with which Russia was inextricably linked, was the defining factor in the primacy of the Slavic culture they so ardently embraced. Distinguishing Russia from the West was therefore a vital imperative to justifying Slavophile ideology and Orthodoxy provided the necessary validation. The inherent mysticism of this argument would appeal to some Eurasianists later on. The importance of Orthodoxy is therefore vital to understanding Slavophilism and also certain aspects of Eurasianist ideology in the future.

Yet, Slavophilism was also a product of its historical environment. Convinced of Russian superiority - mainly due to Imperial Russia's diplomatic and military performances despite its obvious economic and sociopolitical flaws and reinforced by confidence in Orthodoxy’s moral supremacy — Slavophiles began advocating for a rejection of Western Europe in favor of a state based on shared 'Slavic' values. As one scholar noted, "The lack of any economic, political, or institutional base, provided the gentry with a weak sense of distinct social identity. In its place, a feeling of cultural affinity emerged." 12 The "cultural affinity' referred to here is Slavophilism distilled at its most fundamental level. This can best be described as an oversimplified dichotomy between a morally bankrupt Western model versus a Slavic alternative. Slavophiles emphasized the West's spiritual shortcomings because of its excessive materialism, while extolling the moral qualities of Slavic culture. Bordering on utopianism, they placed Slavic culture in direct opposition to the West. It is important to

\footnotetext{
${ }^{11}$ Stepan Shevyrev cited by Jan Kucharzewski, The Origins of Modern Russia, (Trenton, NJ: Polish Institute of Arts and Sciences in America, 1948), 242.

${ }^{12}$ Rabow-Edling, Slavophile Thought, 23. Emphasis added.
} 
note here that the alternative Slavophilism advocated is deeply rooted in Orthodoxy. At times Slavophiles often used the terms Slavic culture and Orthodoxy interchangeably. ${ }^{13}$ To them the Orthodox Church was the spiritual glue that held together all of the Slavic peoples.

This conception expanded into a larger idea that Russia, based on its place in history, should be gravitational center for all Slavic peoples such as Ukrainians, Poles, and Belarusians. ${ }^{14}$ It was also this idea of pan-Slavpholism that led to its ultimate decline as a dominant concept in Russian intellectual thought. The loss of the Crimean War had significantly weakened Imperial Russia. Russia's defeat made clear that fundamental political and economic reform was needed. The death of Nicholas I also reinforced this idea and his successor Alexander II began to ease the extreme societal restrictions put into place by his predecessor. "Contemporaries referred to these changes as the 'thaw' ... the romantic utopianism of the Slavophiles slowly began to disintegrate in favor of practical considerations that ultimately turned out to reflect the concrete class interests of the gentry." 15 Many Slavophiles felt that their society had been overly 'Europeanized' and traced this back to the reign of Peter the Great. They argued that his agenda of Westernization was counterproductive to the creation of a unified Slavic culture and felt that it had created divisions between the nobility and those who still embodied true Slavic virtues. Thus, with the 'thaw' Slavophiles sought to recapture this connection between the nobility and the 'common man' to recreate an imagined common Slavic heritage.

With the emancipation of the serfs in 1861, the Slavophiles felt victorious in liberating the very Slavic peoples they so ardently spoke about. Yet, the thaw also led to turmoil within Imperial Russia. It arguably led to the January Uprising in the Polish-Lithuanian Commonwealth in 1863. While the uprising itself was brutally suppressed by the Russians, it nonetheless permanently damaged the Slavophile idea that all Slavic peoples were united in their interests, which gravitated around Russia. Many leading Slavophiles vehemently attacked the Poles as the "Judas of Slavdom."16 Even Samarin, one of Slavophilism's

\footnotetext{
${ }^{13}$ Irina Livezeanu, "Defining Russia at the Margins," Russian Review 54 (October 1995): 496. See also: Robin Aizlewood, "Revisiting Russian Identity in Russian Thought: From Chaadaev to the Early Twentieth Century," The Slavonic and East European Review 78 (January 2000): 33.

${ }^{14}$ Sergei Trubetskoi, “A Disappointed Slavophile,” (1892; reprint) Russian Studies in Philosophy 46 (Spring 2008): 45-75. It should be noted that there was some dissent to this idea of pan-Slavism. For example Konstantin Leont'ev fervently argued that inclusion of all Slavic peoples would dilute the relevance of Russia. While he was not considered a mainstream Slavophile, he nonetheless warranted responses from important Slavophiles such as Sergei Trubetskoi. Trubetskoi was not only an important figure to the Slavophiles, but his son Nikolai would ultimately become a leading figure in the Eurasianist movement of the 1920s.

${ }^{15}$ Walicki, A History of Russian Thought, 111-112.

${ }^{16}$ Nikolai Danilevsky cited by Dmitry Shlapentokh, "Reassessment of the Relationship: Polish History and the Polish Question in the Imperial Duma," East European Quarterly 33 (Spring 1999): 115.
} 
founders asserted that "Poland was transformed into a 'sharp wedge driven by Latinism' into the very heart of the Slavonic soul with the aim of "splitting it into fragments." ${ }^{17}$ Clearly Slavophilism was transforming itself into an ultra-nationalist conception of Russian statehood. Thus, the Slavophile ideal of pan-Slavism came to an abrupt end and it moved out of mainstream intellectual consciousness. Although there were later iterations of Slavophilism in the late $19^{\text {th }}$ century it never again held the same appeal that it did during the 1830 s to $1850 \mathrm{~s}$ within the popular discourse.

Yet, the importance of Slavophilism to Eurasianism should not be understated. It was the first intellectual movement to articulate many of the same tenets that would later become founding principles of Eurasianism. The idea that Russia did not have to, nor should it, become an integral part of the West European power structure was first stated by the Slavophiles. The salience of Orthodoxy in defining the character of Russian national identity first emerged here as well. Moreover, Slavophile ideas were used, as Eurasianism was later, to justify Russia's great power status through historical precedent and emphasis on Russian achievements. Most importantly the distinctive character of Russian civilization was highlighted as a driving force behind many of these viewpoints. So while Slavophilism's support eventually withered, most of its main concepts were later adopted by the Eurasianists of the 1920s and onwards. The glaring exception, as noted above, would be the near total rejection of pan-Slavism and for good reason - it had been catalyst for Slavophilism's eventual decline.

\section{The Russian Émigré Community and Classical Eurasianism}

Classical Eurasianism first appeared in its most explicit form during the 1920s among Russia's émigré community during the interwar period. These intellectuals were in exile throughout Europe following the turbulent 1917 Russian Revolution. ${ }^{18}$ Yet, they still possessed strongly held views on how Russia ought to conduct and represent itself internationally. This community was by no means homogeneous as it represented all the various ideologies on the political spectrum which were rejected by the Soviets. Yet, for a relatively short period of time from 1920 to 1929, Eurasianism was the dominant ideological movement of this period among the Russian émigré community. It was led by a group of prominent young intellectuals who diverged from the Soviet regime over differences in policy as well as ideology. Composed of economists, philosophers, geographers, ethnographers, and

\footnotetext{
${ }^{17}$ Shlapentokh, "Reassessment of the Relationship," 115.

${ }^{18}$ Serguei Glebov, "The Challenge of the Modern: The Eurasianist Ideology and Movement, 1920-29" (PhD diss., The State University of New Jersey, Rutgers, 2004), 43-55.
} 
even religious thinkers, the classical Eurasianist movement was the product of many diverse fields of study resulting in its prevalence among the émigré community. One should also note that it was this divergence with the Soviet regime that led to its suppression by late 1929- a victim of the USSR's robust counterintelligence campaign to root out perceived antiCommunist ideologies both domestically and abroad.

However, the degree to which Eurasianists opposed the USSR varied greatly. Eurasianism was never wholly in opposition to the Soviets, primarily because Eurasianists saw Bolshevism as a vehicle for extending the influence of the defunct Russian Empire. In essence they saw Bolshevik ideology as a necessary evil. Eurasianists resented the way in which the Bolsheviks had come to power, forcing some of them into exile. The Marxist philosophy of the Bolsheviks, inherently materialist and atheist, was also rejected by the Eurasianists because of its natural opposition to Orthodoxy and its perceived embrace of secular Western thinking. Yet, Bolshevik ideology had some commonly held goals with Eurasianism, insofar as both sought to expand the reach of Russia's borders. The commonalities ended there, however. The Eurasianists saw the continuation and expansion of the Russian Empire as an end in and of itself and justified such a position mainly through the unique geographical location and ethnic composition of Russia. Conversely, the Bolsheviks did so based on the idea that Communism was the natural final stage in the world's socioeconomic development. Hastening this process and spreading Communist ideology was therefore the basis of any territorial ambitions that resembled a Russian empire.

The main leaders of the Eurasianist movement of the 1920s were Nikolai Trubetskoi, Pyotr Nikolaevich Savitsky, Peter Suvchinsky, and George Florovsky who best articulated its core tenets. The first truly Eurasianist text, written by this group, was a collection of essays titled, Exodus to the East (Iskhod k Vostoku) published in Sofia circa 1921. Although influenced by the Slavophile movement of the mid $19^{\text {th }}$ century, and adopting many of its core ideas, these newly formed Eurasianists departed from their intellectual ancestors in some regards. Instead of embracing the idea of pan-Slavism as the Slavophiles had, classical Eurasianists argued in favor of a more wide-ranging Russian identity which included both Slavs and non-Slavs. As Nicholas Riasanovsky, one of the foremost authorities on Russian intellectual history asserts, "Eurasianism proclaimed the new concept of Russia-Eurasia, or simply Eurasia, a distinct and fundamental cultural and historical entity, entirely independent from Europe." 19 Thus, they argued for a distinct Eurasian national identity which justified the

\footnotetext{
${ }^{19}$ Nicholas V. Riasanovsky, "Prince N. S. Trubetskoy's 'Europe and Mankind'," Jahrbücher für Geschichte Osteuropas 12 (July 1964): 212-213.
} 
existence of Russia's multiethnic character. The creation of this new Eurasian identity, primarily founded on a distinctive reading of Russian history, was also a critical factor in justification for the overarching idea of a Russian empire.

In this context the Eurasianist's conception of empire also served as the basis for Russia retaining its great power status during a time when Bolshevism was advocating for the eradication of such imperialist states. The Bolshevik version of communism was thus opposed to Eurasianism on some level as the former sought to promote an ideology that rejected the perceived exploitation of the proletariat. However, some Eurasianists did not wholly agree that such extreme opposition existed between the two ideologies. The anti-colonial and anticapitalist rhetoric, inherently present in Bolshevism, were thus the main basis for its overt rejection of Eurasianist's imperialist ambitions. However, it should be pointed out that Soviet ideology superficially advocated for the destruction of empire. Objectively, the Soviets engaged in just the opposite aligning them, albeit unwillingly, with a fundamental tenet of Eurasianism - primarily the expansion of the state's borders and influence. As a consequence, Bolshevism and Eurasianism were artificially hostile to one another. Yet they both sought to expand and continue Russia's great power status, although they had starkly different visions for achieving this.

Ironically, the nationalist and imperialist impulses of both the Eurasianists and the later Communists would reconcile to a certain extent after the collapse of the Soviet Union in what would be known as 'Greater Russia'. However, to Trubetskoi and his colleagues Russia's "Bolshevization, operated on the ideological coordinates of German Marxism, [illustrating] the perniciousness of Western ideas . . Communism would not have been possible in Russia without an intense 'Europeanization' ..."20 The 1917 Revolution, the primary impetus for many a Eurasianist's own exile, was clearly a major illustration for why the process of 'Westernization' was dangerous for Russia. Yet, Eurasianists never wholly rejected Bolshevik communism, they simply resented that it left them largely out of the policy-making apparatus of the USSR. Thus, the development of Eurasianist ideology was done so under the notion that when Bolshevik communism ended- and it surely would because it was primarily a Western conception - that Eurasianism would be poised to fill the void as the prevailing ideology.

Paradoxically, "The Eurasians tried to preserve the Russian empire by denying its existence. There was no Russian empire, no Russia, only Eurasia, a harmonious, sym- phonic,

\footnotetext{
${ }^{20}$ Emanuel Copilaş, "Cultural Ideal or Geopolitical Project? Eurasianism's Paradoxes,” Strategic Impact (3 2009): 67.
} 
organic association of peoples ..."21 The Eurasianist embrace of Russia's multiethnic national identity provided the necessary justification for its continued presence in historically non-Slavic areas of the eastern and southern portions of Russia. This attitude also reinforces the Slavophile and Eurasianist shared rejection of the Western 'other' as a preferred model for legitimacy. Eurasianist rationale for this is deeply rooted in how its leaders read and understood Russian history - they greatly emphasized periods in Russian history that arguably led to this wide ranging ethnic composition. The period of Mongol dominationknown as the 'Mongol-Tatar Yoke' - is particularly stressed by the Eurasianists as a defining period in the creation of Russian national identity. George Vernadsky, a Russian-American historian, is the most prominent Eurasianist to espouse these views. He constantly reiterated that only through a combination of geographical and historical factors could Russia be fully understood - an entity that he put together" . . . into the only real unity possible, Eurasian Russia."22 In much of his work, primarily on the history of Russia, Vernadsky relentlessly asserted a firm ethnic and sociopolitical connection between Russian Slavs and the non-Slavic peoples of Eurasia. It was this relationship, Vernadsky argued, which was the defining component of the contemporary state they saw before them. Establishing a discernible 'Eurasian' identity was therefore of critical importance to classical Eurasianists.

It is because of this that Eurasianists make the claim that Russia is neither Slavic nor Asian, but in fact a mixture of the two because of this long period of Mongol influence. As Trubetskoi et al assert in their seminal work Exodus of the East the "Russian people and people of the nations of the 'Russian world' [liudi narodov' Rossiiskogo mira'] are neither Europeans nor Asians. Fusing with the native element [stikhiia] of culture and life surrounding us we are not ashamed to recognize ourselves as Eurasians." ${ }^{, 23}$ Eurasianists argued that Russia was not constituted of simply Slavic peoples, but also of 'Turanians' the people of the steppes who consisted of an amalgamation of Finno-Urgic, Turkic, and Central Asian peoples. Even Savitsky rhetorically asked in his essay "Turn to the East" [Povorot k Vostoku] appearing in Exodus, "Is it possible to find in Russia people who don't have khazar or polovtsi, tatar or bachkir, mordve or tchouvache blood? Are there many Russians who are

\footnotetext{
${ }^{21}$ Riasanovsky, ”Prince N.S. Trubetskoy’s ‘Europe and Mankind'," 215.

${ }^{22}$ George Vernadsky, A History of Russia, $5^{\text {th }}$ ed. (New Haven: Yale University Press, 1961), 7. Emphasis added.

${ }^{23}$ Trubetskoi et al. cited by Robin Aizlewood, "Revisiting Russian Identity in Russian Thought: From Chaadaev to the Early Twentieth Century," The Slavonic and East European Review 78 (January 2000): 37.
} 
completely devoided of the oriental mind . ..?"24 Classical Eurasianists consequently embraced the racial lineage that they argued qualified them as 'Eurasian'. As demonstrated before, this distinctive interpretation of Eurasian heritage stemmed from a reading of Russian history that emphasized the Mongol period of hegemony. They claimed that the intermixing of Russians and the Mongols during this period led to the distinctive Eurasian identity they used to justify other aspects of their ideology, primarily its imperial ambitions in areas with little to no Slavic population.

Another important Eurasianist divergence with the Slavophiles emerged when many Eurasianists began to embrace geopolitics as a core precept of their ideology. The importance classical Eurasianism placed on the 'power of place' cannot be understated - it was the main explanation for its criticisms of Eurocentricism that it shared with the Slavophiles. To them Russia inhabited a geographical area that made its great power status preordained. On the other hand, the Slavophiles tended to attribute this destiny more to the mysticism of Orthodoxy, at least more so than did the Eurasianists. Thus, both Slavophiles and Eurasianists agreed that Russia should pursue alternative paths of development, yet their justifications for such a position were quite different. Savitsky was instrumental in promoting the importance of geographical factors among the early Eurasianists - he was a geographer and economist by training. ${ }^{25}$ His ideas would become highly influential to neo-Eurasianists, especially to the work of Lev Gumilev. Yet, the main idea Savitsky sought to move forward was that Russia had been blessed with a geographically advantageous location of 'Eurasia'. Because of this, Russia was meant to have imperial ambitions that bolstered its great power status. Savitsky in particular saw the study of geopolitics primarily as a natural science whereby his methodology sought to illustrate 'Eurasia' as a contiguous geographical entity strategically placed between Europe and Asia. The codification of such a geographic space was thus an overarching goal for the classical Eurasianists during this period.

Despite the robustness of the Eurasianist movement during this period, the Eurasianists still yearned to put their beliefs to practical use. This collective desire led to an eventual split within the movement into two competing factions - those who wanted to ingratiate themselves into the Soviet policy-making apparatus and those who did not. However, the Soviet Union did not view the Eurasianists positively. They created a

\footnotetext{
${ }^{24}$ Savitskii cited by Marlène Laruelle, "The Orient in Russian Thought at the Turn of the Century," in Russia Between East and West: Scholarly Debates on Eurasianism, ed. Dimitry Shlapentokh, 9-37 (Leiden, Netherlands: Brill Publishing, 2007), 33.

${ }^{25}$ An exhaustive account of Savitky's philosophy, methodology, and influence can be found here: Glebov, "The Challenge of the Modern," 188-202.
} 
counterintelligence operation known as 'Trest' (Trust) which ran from 1921-1925 and undermined the various attempts many Eurasianists within the émigré community made to reestablish contact and influence inside the Soviet Union. While the operation is still shrouded in mystery to this day, it effectively sapped much of the enthusiasm from the movement's leadership. It also led to Eurasianism being discredited and widely suppressed for much of the Soviet Union's existence. Those who did manage to find their way into the Soviet hierarchy found that they could not freely promote their Eurasianist ideology under the regime and so subsumed themselves to Soviet orthodoxy. While some Eurasianists managed to subversively keep classical Eurasianism alive in one form or another, it would never again reach its zenith of enthusiasm - at least in its most classical sense - of the mid 1920s.

\section{The Reemergence of Eurasianism: Neo-Eurasianism}

During the Soviet period Eurasianism was heavily suppressed by state officials. Those Eurasianists who managed to stay within the Soviet Union and in its political and intellectual circles, did not actively advocate for Eurasianism as a whole. Instead they sought to keep alive certain ideas that the Eurasianists first espoused within these influential groups. Rather than advocating for a Eurasianist ideology - a move that would have blacklisted them and their ideas - these hidden Eurasianists sought to insert some tenets of their ideology into official Soviet doctrine. The success of these efforts was mixed at best and evidence of Eurasianist thought inside the Soviet Union did not appear until the 1980s during Gorbachev's perestroika. The two most prominent Eurasianists who began to more aggressively assert Eurasianist concepts at this time were the late historian Lev Gumilev, and the controversial academic Aleksandr Dugin. The tandem helped bridge the gap between the Communist regime and the immediate period following the collapse of the Soviet Union. Thus, Gumilev was instrumental in keeping the Eurasianist flame alive during the Soviet period and immediately up to its collapse, while Dugin was the central figure in Eurasianism's revival after Yeltsin took office. Most importantly, Dugin was vital to Eurasianism's transformation into a new geopolitical vision for Russian foreign policy.

When the Soviet Union officially dissolved on Christmas day 1991 a massive ideological void was created in its wake. The population of the newly formed Russian Federation was in the midst of a severe identity crisis. It struggled with two fundamental questions: What is Russia? And also who is Russian? The Russian leadership was desperately seeking definitive answers to these fundamental questions. Many competing visions emerged from the Soviet wreckage, from liberals, communists, nationalists, conservatives, and 
democrats to list just a few- all tried to put forth their visions for the future direction of Russia. Eurasianism too was also undergoing a powerful resurgence among the political and intellectual elite. The focus of this section will be on this resurgence. Yet, it is still important to note that the prevailing ideology among most members of the Yeltsin administration was liberal in nature. Eurasianism, while not the official doctrine of Yeltsin's government, nonetheless underwent an important formative period during his years in office. The Yeltsin era's "inability to clearly situate Russian frontiers" allowed Eurasianism to provide the necessary "ideological foundation for post-Soviet imperialism.,"26 The revival of Eurasianism - or as it came to be known, 'neo-Eurasianism' - can mainly be attributed to its opposition to Yeltsin's pro-Western shift in foreign policy thinking and a collective nostalgia for the imperial past. This antagonistic attitude towards pro-Western elements in Russia became the centripetal force needed to make Eurasianism an attractive alternative to what many saw as a fundamental weakening of the Russian state.

Eurasianism still existed, albeit in a diminished form, immediately leading up to the Soviet Union's dissolution. Lev Gumilev, a prominent Eurasianist historian, is most known for his theory concerning the development of civilizations. Terming it 'ethnogenesis' his scholarship was concerned with how groups of people eventually organized themselves into distinct civilizations. He developed most of his theories regarding ethnicity mainly during the 1980s, but he did not become particularly relevant to the revival of Eurasianism until perestroika, when he was free to more fully articulate his ideas. Adopting many of the same precepts of the early Eurasianists, Gumilev asserted that the Mongol era served as the key turning point in the creation of a 'Eurasian' identity. Arguing that this was an objective, almost scientific truth, Gumilev regarded this as a positive development and the seminal moment in developing the distinctive conception of a national identity for Russia. According to his idea of ethnogenesis, this combination of two 'ethnoses' - Russian and Central Asian - created a subsequent "super-ethnos" which can best be understood as a distinct civilization unto itself. This identity was central to Eurasianism in establishing a unique vision of Russia as an alternative civilization to that of the West. Thus, the essence of his ideas can best be boiled down to the process of creating a nation. Unfortunately, Gumilev would not see how his Eurasianist ideas and theories would continue to develop past his death in 1993. His contribution to its revival however, should be noted for introducing a 'scientific' approach to the ideology and also his emphasis on the Eurasian heritage of Russian ethnicity and the

\footnotetext{
${ }^{26}$ Françoise Thom, “Eurasianism: A New Russian Foreign Policy?” Uncaptive Minds 7 (Summer 1994): 76.
} 
ensuing geographical formation of a Russian nation-state-concepts that would later become important parts of neo-Eurasiansism.

Marlène Laruelle, one of the foremost scholars of Eurasianism, insists that Gumilev was not the 'Last of the Eurasianists', but instead posited that his successors popularized the notion. ${ }^{27}$ In any case his legacy as the last Eurasianist, at least in the most traditional sense, was promoted greatly by a group he would heavily influence - the neo-Eurasianists. ${ }^{28}$ If Gumilev is indeed the last Eurasianist in the most classical sense, then Aleksandr Dugin is assuredly the first neo-Eurasianist. Much has been written about this man and his ideas. He is without a doubt the most prolific author and advocate of neo-Eurasianism. When the Soviet Union disintegrated, Russia was forced to undergo a fundamental transformation of its foreign policy. For the first time in decades the Communist ideological impetus for Russian foreign policy was gone. In its place policy had to be based on rational national interest instead of the messianic role Marxism had given it. Much of Yeltsin's tenure, especially in the mid to early nineties, can be characterized as pro-Western and Atlanticist. His regime sought rapprochement with the West. As a consequence, this strategy of détente led to a strong and vocal opposition which vehemently opposed such extensive cooperation with the West. Many factions would voice these concerns, but it was the neo-Eurasianists who were able to gather the most support. While they lacked any prominent political party, the neo-Eurasianists nonetheless provided a cohesive foreign policy alternative to what Yeltsin and his coterie advocated. While there were many figures who subscribed to tenets of neo-Eurasianism, both in and out of the policymaking sphere, it is Dugin who is most relevant to this study.

The reason for this is twofold. First, Dugin has been the most influential neoEurasianist. He served as a foreign policy advisor to the former Chairman of the Duma, Gennadii Seleznev, and some of his publications such as Den (The Day) have garnered "the support of the chief political directorate of the [Russian] armed forces." ${ }^{29}$ Additionally Dugin has "gained access to the inner circle of Putin's Kremlin. As a result of these connections,

\footnotetext{
${ }^{27}$ Marlène Laruelle, "Histoire d'une usurpation intellectuelle : L. N. Gumilev, 'le dernier des eurasistes' ? Analyse des oppositions entre L. N. Gumilev et P. N. Savickij [History of intellectual theft: L. N. Gumilev, 'the last of the Eurasianists'? Analysis of contrasts between L. N. Gumilev and P. N. Savickij]," Revue des études slaves 73 (2001): 449-459. The author disagrees with most modern neo-Eurasianists who herald Gumilev as the last 'true' classical Eurasianist and instead argues that Savitsky can more legitimately hold this title.

${ }^{28}$ Sławomir Mazurek, "Russian Eurasianism: Historiosophy and Ideology," trans. Guy R. Torr, Studies in East European Thought 54 (March 2002): 106.

${ }^{29}$ Walter Laqueur, Black Hundred: The Rise of the Extreme Right in Russia, (New York, NY: Harper Collins Publishers, 1993), 139.
} 
Dugin played a central role in drafting the 2000 National Security Concept." ${ }^{, 30}$ Second, and just as significant, his abundance of publications has provided the most cogent articulation of neo-Eurasianism. For these reasons Dugin will be the primary focal point for a discussion on neo-Eurasianism. While there were others during this time period, and even today, who can be categorized as such it is Dugin who provides the best expression of how the many threads of Eurasianism's development would later be interpreted by the contemporary political elite of Russia. The current type of Eurasianist foreign policy, which began to be implemented under Putin in 2000, has largely been informed by Dugin's conception. While not completely conforming to it, Russian foreign policy rhetoric and overall goals since 2000 can best be understood with a thorough understanding of Dugin's neo-Eurasianist doctrine.

During the nascent stages of Dugin's work in the early nineties, most of his publications appeared in two journals - Den (The Day) and his own journal Elementy (The Elements). Here Dugin began to construct his neo-Eurasianist doctrine. As mentioned previously, Den was particularly influential among the elite in the Russian military. On the pages of these journals Dugin began to assemble a new interpretation of Eurasianism that greatly emphasized the importance of geopolitics to Russian foreign policy. During most of the nineties, however, Dugin was relegated to the periphery of Russian politics by those aligned with Gorbachev's 'new thinking' and also by outside observers. He was widely associated with different elements of Russian nationalist groups, as well as other conservative political entities. However, during the Yeltsin years Dugin slowly ingratiated himself into more mainstream Russian political discourse through a number of increasingly influential contacts within the Russian political and military elite. ${ }^{31}$ Culminating with his seminal work, Osnovy geopolitiki: geopoliticheskoe budushchee Rossii [Foundations of Geopolitics: the geopolitical future of Russia] first published in 1997, Dugin increasingly transformed the focus of his neo-Eurasianism into a largely geopolitical doctrine which still held firm to certain elements of classical Eurasianism. This book is regarded by many to be moment at which many of his ideas began to inform Russian policymaking, a few years before Vladimir Putin ascended to the Presidency. ${ }^{32}$

\footnotetext{
${ }^{30}$ Jeffrey Mankoff, Russian Foreign Policy: The Return to Great Power Politics (Plymouth, UK: Rowman \& Littlefield Publishers, 2009), 67; See also: John Dunlop, “Aleksandr Dugin's 'neo-Eurasianist' Textbook and Dmitrii Trenin's Ambivalent Response," Harvard Ukrainian Studies 25 (Spring 2001): 96-98.

${ }^{31}$ Laruelle, Russian Eurasianism: An Ideology of an Empire, 108-111. The author provides an in depth overview of the various political connections Dugin made during this period.

32 Alan Ingram, "Alexander Dugin: geopolitics and neo-fascism in post-Soviet Russia," Political Geography 20 (2001): 1032; See also: Marlène Laruelle, “(Neo-) Eurasianists and Politics: 'Penetration' of State Structures and Indifference to Public Opinion?” Russian Politics and Law 47 (January-February 2009): 98.
} 
By 2001 Dugin began to articulate a set of principles which constituted a particular neo-Eurasianist doctrine which has been associated with him ever since. Supportive of Putin's Presidency and agenda, Dugin began to lay out the framework for his conception of how Russian foreign policy should look. He distilled the main objectives of his doctrine thusly:

\begin{abstract}
"Contemporary Russia can be saved as an autonomous and independent political reality, as a valuable subject of international policy, only in the conditions of a multipolar world. Consenting to the unipolar American-centred world is impossible for Russia, since in such a world she could be but one of the objects of globalisation, inevitably losing her independence and originality. The opposition to unipolar globalisation, the assertion of the multipolar pattern is the major imperative of contemporary Russian foreign policies." 33
\end{abstract}

Clearly Dugin's vision is reminiscent of the 'third way' Laruelle has highlighted as an underlying current for most of Eurasianism's history and he even uses the same term himself when describing his doctrine. He fully supports the idea that Russia should pursue an alternative course that is entirely its own. To that end he argued "that Russia has its own way. And this way does not coincide with the main route of Western civilization." ${ }^{34}$ This alternative path was not necessarily antagonistic to the West, but instead saw everything associated with it to be destructive and potentially harmful. Tellingly Dugin, in an effort to recruit university students, claimed that "Everything that comes from America, is impregnated with poison." 35 This opposition to the West is indicative of much of neo-Eurasianism's resurgence. The failed reforms under Yeltsin, coupled with the economic turmoil of the 1990s succeeded in associating the West with instability and chaos. As a result, opposition to, or at the very least rejection of, Western modes of development once more became a cornerstone of a distinctly Eurasianist doctrine. This tenet of Dugin's neo-Eurasianism would become even more important as it began to be applied to the international system and Russia's place within it.

Significantly, he asserted that his conception was "not only emotional, but scientific, based on geopolitics and its methods ... We can say that 'Eurasia' is a geopolitical party."36 Dugin's conception can therefore be best understood as a dualistic set of principles. First, it rejects the idea of a unipolar international system and instead promotes a multipolar

\footnotetext{
${ }^{33}$ Aleksandr Dugin, "Main Principles of Eurasist Policy," trans. Martino Conserva, 2001, <http://www.evrazia.org/modules.php?name=News\&file=article\&sid=421> (Accessed May 10, 2012).

${ }^{34}$ Aleksandr Dugin, "Eurasianism: From Philosophy to Politics," Nezavisimaya Gazeta, May 30, 2001, <http://www.ng.ru/ideas/2001-05-30/8_philosophy.html> (Accessed June 10, 2012).

${ }^{35}$ Aleksandr Dugin, "Catechism of member of the Eurasian Youth Union," <http://www.rossia3.ru/katehizis.html> (Accessed May 13 ${ }^{\text {th }}, 2012$ ).

${ }^{36}$ Aleksandr Dugin, "We- The Party of the National Idea" (Speech at Political Conference, All Russian Political Public Movement, March 1, 2002). <http://www.evrazia.org/modules.php?name=News\&file=article\&sid=736> (Accessed May 12, 2012).
} 
alternative. In his view this is the only way for Russia to regain its great power status-a recurrent theme under Putin's regime - by rejecting perceived American cultural imperialism and unilateralism. As a consequence, opposition to the West is a central tenet of his neoEurasianist doctrine. Second, the guiding principles that inform such a foreign policy approach rest primarily on a geopolitical strategy of 'spheres of influence' and 'privileged areas of interest'. As Dugin himself explains, his doctrine "conceptualizes such [a] foreignpolicy course [sic] and substantiates it by the scientific methodology of geopolitics." ${ }^{37}$ Much like Gumilev, who was convinced of the scientific merits of his theory of ethnicity, so too was Dugin in his certainty that the study of geopolitics revealed an objective truth- a clear set of understandable precepts which dictate state behavior within the international system.

As a consequence, Dugin consistently highlights the importance of Russia's unique geographical location and ethnic heritage as the main pillars for Russia's deserved great power status. His work after the publication of Osnovy geopolitiki became saturated in classical geopolitical theory which can be traced back to the first geostrategists. Elements of Halford Mackinder, Alfred Thayer Mahan, Nicholas Spykman and even Karl Haushofer all appear to have influenced Dugin's geopolitical thinking in some way. Most tellingly Dugin sees Russia's challenge to the West not only in terms of Russia's unique ethnic composition and Orthodox heritage, but through a historically inevitable rivalry between land-based powers (tellurocracies personified best by Russia on the Eurasian landmass or 'heartland') and their sea-based adversaries (thalassocracies represented by the West, especially America). According to Dugin this competition was based on the former's inclination to "respect cultural differences and variety, whereas sea-based powers aspire to control their surroundings through imposing political, economic, and cultural homogeneity upon them."38 Consequently, opposition to Atlanticist powers was entrenched in Dugin's doctrine on a most basic level. The importance of Russia's strategic location at the center of Mackinder's fabled 'heartland' poised Russia, in Dugin's view, to become a major power within the international system. The teleological unity of Dugin's arguments complimented Russia's new great power ambitions that would come to define Vladimir Putin's foreign policy doctrine.

The rhetorical usage of derzhavnost or great power status would become a frequent motif of Putin's administration. Significantly, Putin used the term in his official statement announcing his presidential platform. The importance of this rhetoric was not lost on anyone inside Russia. The Moscow Times pointed out the importance of this "imperial term

\footnotetext{
${ }^{37}$ Dugin, "Main Principles," <http://www.evrazia.org/modules.php?name=News\&file=article\&sid=421>

${ }^{38}$ Yigal Liverant, "The Prophet of the New Russian Empire," Azure 35 (Winter 2009): 66.
} 
'derzhavnost', or belief in the state's greatness. The word is derived from 'derzhava', or the orb that was part of the tsarist regalia and which signified imperial global reach." 39 The reclamation of Russia's status as a major power in the international system was clearly the overarching objective from the outset of Putin's rise to power. Putin's rhetoric made him an attractive candidate to Dugin and explains how Dugin went from dissident to government supporter during the late nineties and into the new millennium. Dugin argued that Putin's policies represented "the historical interests of a social and national majority" which were based on "geopolitics, implementing national interests and accepting the challenge of history." ${ }^{40}$ While the amount of reciprocation on Putin's part with regards to Dugin has varied and is widely debated by many, the parallels between certain aspects of Dugin's neoEurasianist doctrine and Putin's foreign policy are striking. Dugin continues to be a major voice in Russian political and intellectual life and has vociferously maintained his advocacy of neo-Eurasianism's inclusion in Russia's foreign policy discourse.

\section{Continuity and Divergence}

It has become readily apparent during the course of this chapter that the idea of Eurasianism is by no means invariant. Eurasianism is thus best understood through an acceptance of its heterogeneous character. There are many lines of continuity that have been illustrated and also some differences since its origins in the $19^{\text {th }}$ century. Russia, for a variety of historical and geographic reasons, has always struggled with its conception of itself. This perpetual debate- between those who want to integrate into the international system along the same route as other Western powers and those who would like to follow an alternative path- has ultimately shaped how Eurasianism was first established and how it has evolved into its more contemporary iterations. Throughout its evolution a few threads of continuity exist. First, the idea of Russia as a distinctive 'Eurasian' power which is inherently at odds with the West (albeit to varying degrees) has been present throughout Eurasianism's existence. Second, an innate desire to preserve Russia's unique cultural heritage in a world that it views as increasingly culturally homogeneous has been present in all three stages of Eurasianism's development. Third, the notion that the various theories of ethnicity and geopoliticsunderlying many of its main tenets - are not mere conjecture, but instead border on objective truths has been present throughout.

\footnotetext{
${ }^{39}$ Garfield Reynolds, "Putin Gives People Paternal Patriotism," The Moscow Times, December 30, 1999, <http://www.themoscowtimes.com/news/article/putin-gives-people-paternal-patriotism/268321.html> (Accessed June 10, 2012).

${ }^{40}$ Aleksandr Dugin, "Putin's Defensive Anti-Americanism,” Vremya Novostei, March 10, 2003, <http://www.vremya.ru/2003/64/48/34759.html> (Accessed June 10, 2012).
} 
Conversely, Eurasianism has undergone many changes throughout its development. These variances have been emphasized over the course of this section. However, the aspects that have become the most salient to Dugin's neo-Eurasianism warrant the most attention. The intense focus on geopolitical considerations, along with a reflexive anti-Western doctrine, has largely found their way into contemporary Russian foreign policy in one form or another. The specific variety of Eurasianism that has found its way into official Russian policy will be fully articulated in the following section. Yet, its roots can be traced back to Slavophilism of the $19^{\text {th }}$ century, Classical Eurasianism of the early $20^{\text {th }}$, and the neo-Eurasianism that appeared in the post-Soviet period. These three important developmental periods in Eurasianism's existence have ultimately led to the creation of what this study terms 'geopolitical Eurasianism'. This new type of Eurasianism is what best characterizes Russian foreign policy over the past decade. Its formation was a culmination of Eurasianist thinking from these three distinctive developmental periods. Thus, understanding the historical context in which it was developed helps in understanding the latest expression of Eurasianism in a contemporary setting.

\section{Towards a New Eurasianism?}

For all of Eurasianism's variance, there still remains a core set of principles that sets it apart from opposing doctrines or philosophies. The resurgence of neo-Eurasianism following the collapse of the Soviet Union has been the most recent incarnation of Eurasianism. As a result, neo-Eurasianism, specifically the approach promoted by Dugin, has become the most significant doctrine to inform a new type of Eurasianism that has been slowly developing since Putin's ascent to the Presidency in 2000. It is this new variant of Eurasianism that will be the focus of the remainder of this study. It has taken aspects from the various earlier strands of Eurasianism throughout its history and created a distinctive variety that has found fertile ground in the post-Soviet era. Most importantly, this new type of Eurasianism has become increasingly salient to the formulation and implementation of contemporary Russian foreign policy. This particular doctrine can be defined as 'geopolitical Eurasianism' and it has come to be a dominant doctrine in shaping Russian foreign policy. At its core geopolitical Eurasianism is a set of principles that is extensively informed by Dugin's version of neoEurasianism. It also contains elements of Slavophilism and Classical Eurasianism although to lesser degrees. The main tenets of this new Eurasianism can be condensed into three basic principles. 
First, geopolitical Eurasianism rejects Western socioeconomic and political modes of development. Instead it seeks an alternative route that is essentially equivalent to the idea of a 'third way's, a distinctly Russian path for advancement which has been a hallmark of Eurasianism throughout its existence. Geopolitical Eurasianism does not create a Russia that is necessarily anti-Western, but instead creates a national identity that is wholly nonWestern - an important distinction from Dugin's neo-Eurasianism and even its Classical variant. It resents many existing international institutions and views them as vehicles to further only 'Western' interests. Consequently, geopolitical Eurasianism uses these institutions to promote Russia's interests and, where necessary, creates its own alternative institutions when this is not possible. The chaotic and tumultuous decade following the dissolution of the Soviet state has made these positions simultaneously tenable and desirable from the vantage point of the Russian Federation. The turbulent Yeltsin years scarred Russia's post-Communist experience and left an indelible impression on them. Associating that period with the Yeltsin's administration's extensive cooperation with the West has provided ample justification for this central tenet of geopolitical Eurasianism.

The second principle of this particular version of Eurasianism is a reassertion of Russia's great power status. It rejects the notion of an international system dominated by only one power and seeks to promote a multipolar environment with Russia representing one of the poles. To that end the creation of an alternative network of states, composed mainly of former members of the Soviet Union (particularly in Central Asia), are a main foreign policy objective. Russia has been adamant it does not wish to resurrect the Soviet Union and has sought to emphasize that point publicly and often. Yet, as Putin himself famously declared, "The collapse of the Soviet Union was a major geopolitical disaster of the century."41 Nostalgia for its past great power status has been evident in Russia since the Soviet Union's collapse. The Russian Empire's coat of arms was reestablished as the official symbol of the Russian Federation in 1993 - a double-headed eagle symbolically looking towards both the east and the west. Moreover, Putin has even reinstated the Soviet Union's anthem, albeit to alternative lyrics. Both of these actions consciously symbolized Russia's continued great power ambitions. Recent military and political actions, such as its 2008 war with Georgia and Putin's recent proposal for a 'Eurasian Union' point to Russia reasserting itself as a great

\footnotetext{
${ }^{41}$ Vladimir Putin, "Annual Address to the Federal Assembly of the Russian Federation” (The Kremlin, Moscow, April 25 2005). <http://archive.kremlin.ru/eng/speeches/2005/04/25/2031_type70029type82912_87086.shtml> (Accessed June 15, 2012). It should be noted that this quotation has often been mistranslated as 'greatest geopolitical catastrophe of the century'. While the difference may seem subtle, many scholars argue that 'disaster' more appropriately reflects Putin's original intention.
} 
power, especially within its 'near abroad'. Concurrently, they also demonstrate a reflexive rejection of Western involvement in areas the Russian leadership sees as Russia's 'privileged spheres of influence'. ${ }^{42}$ These actions are evidence of a pattern of imperialist and neoImperialist impulses as a basis for realizing this great power status. Eurasianism has historically been used to justify an imperial Russia by both the Slavophiles and the Classical Eurasianists. Thus, a strategy of reasserting control over neighboring states — with varying degrees of success as the series of 'colored revolutions' has shown- is a significant part of the geopolitical Eurasianist doctrine and coincides with its objective of becoming a powerful successor to the Soviet state. As a result it has systematically sought to bring former Soviet republics back into its orbit and when this is not feasible prevent them from gravitating towards the West.

The third, and final, pillar of this Eurasianist doctrine is perhaps the most obvious, but also the most salient — an emphasis on geopolitics. Geopolitical Eurasianism consistently emphasizes the importance of Russia's geographical location between Europe and Asia. Geopolitics is a way of viewing the world as distinctive areas of geographic, economic, and strategic importance all situated in a competitive global environment. This has also motivated the additional attention Russia has given to its neighbors to its southern and eastern borders over its more publicized relations with the West. The importance of place is not only borne out of a rationale political calculus, but also of political necessity. Demographic trends, mainly in the eastern portions of Russia, have led to a dramatic depopulation of ethnic Russians from economically and strategically important regions such as Siberia and the far eastern reaches of the country. ${ }^{43}$ Simultaneously, this has encouraged a positive net migration of Central Asians and Asians into many of these areas, loosening the amount of power Moscow is able to wield in these places. The combination of ethnic Russian population loss with an increase in non-Russian immigration has caused Russia to question its ability to maintain control over these valuable areas. As early as 2000 Russia acknowledged the growing importance of Asia to its foreign policy which it attributed to "Russia's direct affinity with this dynamically developing region and the need for an economic upturn in Siberia and

\footnotetext{
${ }^{42}$ Roger McDermott, "Moscow Fears Shift in Central Asia’s Strategic Balance Post-2014,” Eurasia Daily Monitor 9 (June 22, 2012), <http://www.jamestown.org/programs/edm/single/?tx_ttnews[tt_news]=39523\&cHash=992b418ce8d96460bc98 ad6b6ea49237> (Accessed July 23, 2012).

${ }^{43}$ VCIOM, "Siberia and the Far East: 'Forgotten Land' or 'Engine of Development'?"

$<$ http://wciom.com/index.php?id=61\&uid=682> (Accessed July 12, 2012).
} 
the Far East." ${ }^{44}$ Moreover, the specter of a rising China has caused Russia to reevaluate its role in East and Central Asia. ${ }^{45}$ Above all it fears becoming a junior partner to an increasingly powerful neighbor. The creation of a multiethnic identity for Russian statehood-

underpinned both by its geographical location and its ethnic composition of Russians and nonRussians - is therefore crucial to this doctrine's underlying geopolitical logic. This logic is also what has made Geopolitical Eurasianism so appealing to contemporary Russian foreign policy — it has helped Russia adapt to changing realities in the international system. Clearly, the primacy of place, especially as it relates to Russia's role in Central Asia, is a significant aspect of this doctrine.

The emergence of the term 'blizhneye zarubezhye' (near abroad) as a colloquial expression for what Russia sees as its historical 'privileged sphere of influence' also points to this refocusing on geopolitics. The term 'near abroad' was first used during the early nineties as a "claim by Russia of political interest and influence in states adjacent to it that were once part of the Soviet Union." ${ }^{46}$ The term is widely used to delineate what Moscow views as Russia's areas of privileged influence. The choice of this term also points to a reassertion of Russia's dominant role in regions that were once part of the former Soviet Union. The logic behind these ambitions is blatantly geopolitical in nature. Its focus on the creation of 'spheres of influence' is a clear geopolitical objective that Russia would like to sustain. Yet, this Eurasianist doctrine can trace these geopolitical developments back to two of its main developmental periods. Clearly Dugin's neo-Eurasianism, with its focus on the logic of geopolitics, has influenced this doctrine the most. Classical Eurasianists has also embraced the study of geopolitics as a foundation of their philosophy. The influence of classical geopolitical thought, particularly the ideas of Mackinder and Mahan, have repeatedly been used to undergird many Eurasianist assumptions on the importance of Russia's geographical location. Moreover, the political use of Russia's location between Europe and Asia contributes to the idea that Russia is composed of peoples that are neither purely Russian nor Asian, but a mixture of the two. This combination is distinctly 'Russian' in nature and allows for Russia to create a foreign policy based on the concept that it is a uniquely 'Eurasian' state

\footnotetext{
${ }^{44}$ Vladimir Putin, "The Foreign Policy Concept of the Russian Federation," Ministry of Foreign Affairs of the Russian Federation (June 28, 2000), <http://www.fas.org/nuke/guide/russia/doctrine/econcept.htm> (accessed May 26, 2012).

${ }^{45}$ Thomas Grove, "Russia's Medvedev hints of Chinese threat to Far East," Reuters, August 9, 2012, <http://www.reuters.com/article/2012/08/09/russia-china-territory-idUSL6E8J98K520120809> (Accessed August 10, 2012).

${ }^{46}$ William Safire, “On Language; the Near Abroad," The New York Times, May 22, 1994, <http://www.nytimes.com/1994/05/22/magazine/on-language-the-near-abroad.html> (Accessed June 15, 2012). Article neatly explains the usage of the term and its historical significance.
} 
straddling the West and the East as Russia's double-headed eagle, looking in both directions on its coat of arms, suggests. These geopolitical considerations have been the strongest link to this new Eurasianist doctrine and its historical legacy.

The three main tenets of Geopolitical Eurasianism - a rejection of Western modes of development in favor of its own, a reassertion of Russia's great power status, and a geostrategic approach to the international system - have become increasingly present in contemporary Russian foreign policy. It has become progressively more evident, since Vladimir Putin's rise to power in 2000, that the guiding doctrine of Russia's foreign policy is Eurasianist in nature, specifically Geopolitical Eurasianism, as outlined above. This process has been incremental, but has recently culminated with Putin's third term as President. A full understanding of this doctrine is crucial to understanding the current trajectory of Russian foreign policy going forward. To that end the following section will present a growing body of evidence as to why this is the prevailing paradigm in Russian foreign policy, demonstrate the process by which it became increasingly more Eurasianist, and highlight the most important events in this transformation.

\section{The Disillusionment of the 1990s}

In the 1990s Russia would experience a very chaotic and tumultuous decade under the leadership of Boris Yeltsin. His tenure as President of the Russian Federation would largely lay the foundation for the Russian foreign policy after his resignation. Widely perceived as incompetent, Yeltsin presided over a series of very serious crises that would come to define Russia's political landscape — the 1998 'Ruble Crisis', the eastward expansion of NATO, and the Kosovo War. These three events, and Yeltsin's inept response to them, laid the groundwork for Putin's rise to power and increased the appeal of alternative visions for Russian foreign policy. The decade following the Soviet Union's collapse ushered in a period of cooperation and détente between Russia and its Western partners that had never been seen before. Prospects at the beginning were very bright, especially in Russia where Yeltsin and his administration were largely seen as Liberal reformers open to collaboration. As the decade unfolded, however, it became apparent that a reciprocal relationship with the West was not developing as the Russians had expected. Instead the West increasingly took a series of actions that humiliated Russia internationally, delegitimized the Yeltsin regime domestically, and poisoned future prospects of a mutually beneficial relationship. The Western intervention in Kosovo, its continued expansion of NATO, and its perceived association with the 1998 
financial crisis contributed to the view that cooperation with the West was untenable because Russian interests were not being truly respected.

In the immediate aftermath of the Soviet Union's collapse, Western advisors quickly came to Moscow to help develop a plan for Russia to liberalize and modernize its economy. The plan, dubbed the 'Washington Consensus', was a ten-point series of economic recommendations that was backed by the International Monetary Fund (IMF), World Bank, and the U.S. Treasury department. When Yeltsin's administration implemented many of these proposals, the subsequent 'shock' to the Russian economy was enormous. Many Russian's quickly saw their standard of living decrease dramatically, while a select few enriched themselves on state assets. The growing disparities between rich and poor along with the dramatic decrease in living standards was quickly associated with the 'Washington Consensus' and the involvement of the Western institutions which were recommending the policies to the Yeltsin administration. The continued economic hardships of the 1990s strengthened many of Yeltsin's political opponents and sapped much of his political capital. Yeltsin, the West (especially the United States), and the economic chaos were thus closely associated with one another. As the head of the IMF stated at the time, "the amount of assistance will depend on progress with economic reforms," further solidifying this association. ${ }^{47}$ Leading up to the 1998 financial crisis in Russia, Yeltsin would be forced to make political concessions with many of his more hard-line opponents. The clearest example was Yevgeny Primakov's rise to Foreign Minister and later to Prime Minister- a series of promotions from which Yeltsin tried to leverage political support.

By 1998 Russia was in serious economic turmoil. The country had been severely affected by the Asian financial crisis the previous year and commodities markets, upon which Russian government revenue was highly dependent, had collapsed. In response Yeltsin dismissed his entire cabinet, throwing his administration into political chaos. As investor confidence plummeted, and despite a substantial financial package from the IMF and World Bank, Russia would eventually default on its debt by August of the same year. This default, sometimes called the 'Ruble Crisis', had a devastating impact on Yeltsin's credibility as Russians' life-savings were virtually wiped out in its aftermath. His administration's cooperation with the West, its implementation of Western recommendations, and the subsequent failure of the 'Washington Consensus' would ultimately discredit Yeltsin and

\footnotetext{
${ }^{47}$ Thomas Friedman, "I.M.F. Head Defends Russia Loan Policy Against Criticism," The New York Time, February 2, 1994, <http://www.nytimes.com/1994/02/02/world/imf-head-defends-russia-loan-policy-againstcriticism.html?pagewanted $=$ all\&src $=$ pm $>$ (Accessed August 12, 2012).
} 
undermine his administration's ability to govern. Yeltsin was only able to recover marginally after making appointments to his cabinet that were political concessions to his opponents. ${ }^{48}$ Most importantly, however, the crisis reinforced the notion popular among Yeltsin's opponents that cooperation with the West was not a positive-sum game where both parties would mutually benefit from collaboration. Instead it underlined for many that Russia's relations with the West would always be zero-sum in nature and should be approached as such.

Adding insult to injury, in 1999 NATO conducted a sustained air campaign in an effort to intervene during the Kosovo War despite strong Russian protests not to intercede. Defying the UN Security Council's veto on military action, NATO conducted extensive airstrikes against Serbia and its leader Slobodan Milošević. As Yeltsin himself forcefully stated, "This is a very serious step and to take it without the UN Security Council is more than inexplicable." ${ }^{49}$ Russia, a traditional ally of the Serbs, viewed this intervention as a direct affront to Russian interests in Europe. The Kosovo War would not be easily forgotten. Most tellingly, years after the conflict, an anonymous Russian Deputy Foreign Minister issued a warning to the U.S. Embassy in Moscow stating that "Kosovo's bid for independence from Serbia -- a move which was favored by the US -- would 'set a precedent." "50 The NATO-led intervention in former Yugoslavia would without a doubt have important implications for the future of Russian foreign policy. While Yeltsin himself famously declared that he would prevent NATO from 'touching Kosovo ', his rhetoric proved to be empty. Despite Moscow's bluster, NATO successfully intervened in Kosovo, a fact which would become a festering political wound for Yeltsin until his resignation.

A few weeks before Kosovo, NATO had just completed a round of enlargement incorporating Poland, Hungary, and the Czech Republic, which increased Russia's frustrations with the West. Yeltsin's administration was eventually cowed into a reluctant acceptance of this, which culminated with the signing of the "Founding Act on Mutual Relations, Cooperation and Security," 51 a document that codified Russia's tepid agreement to

\footnotetext{
${ }^{48}$ Yevgeny Primakov is the best example of this. His appointment as Prime Minister after the crisis contributed largely to the stabilization of Russia's political environment after the default.

${ }^{49}$ Melissa Akin, "Moscow Outraged By Attack on Serbs," The Moscow Times, March 25, 1999, $<$ http://www.themoscowtimes.com/news/article/moscow-outraged-by-attack-onserbs/279062.html\#ixzz25irKz1FC> (Accessed August 12, 2012).

${ }^{50}$ Uwe Klussmann, "Cables Track US Diplomatic Efforts to Avert Russian-Georgian Conflict," Der Spiegel, December 1, 2010, <http://www.spiegel.de/international/world/0,1518,732294,00.html> (Accessed December 1, 2011)

${ }^{51}$ North Atlantic Treaty Organization, "Founding Act on Mutual Relations, Cooperation and Security between NATO and the Russian Federation," Paris, France, May 27, 1997, <http://www.nato.int/cps/en/natolive/official_texts_25468.htm> (Accessed June 12, 2012).
} 
this round of enlargement. This represented a seminal moment that many of Yeltsin's opponents viewed as further evidence of his administration's weakness. The prominent opposition leader Gennady Zyuganov complained that the treaty was "practically an act of capitulation" and was a forceful statement in line with his previous condemnation of the NATO-led intervention in Kosovo. ${ }^{52}$ This expansion was possible because it relied "not on Russian consent, but on Russian weakness," as foreign policy expert Michael Mandelbaum explained at the time. ${ }^{53}$ Ironically Yeltsin thought he had extracted sufficient concessions from NATO, emphatically insisting before the document's ratification that former Soviet Republics "not be drawn into NATO in any form." 54 After signing the document, Yeltsin prophetically stated, "If NATO decides to accept former Soviet republics as its members, Russia will re-examine its relations with NATO." ${ }^{55}$ Clearly, the expansion of NATO, along with Yeltsin's inability to stop it, was a growing point of irritation to Russia. To Russia's leaders, the growth of the Cold War military alliance was little more than an unnecessary provocation by the West during a period of Russian weakness. This political environment provided fertile ground for alternative visions for how Russia should fashion and implement its foreign relations.

The ineffectual nature of the Yeltsin years, widely perceived within Russia as overly deferential to the West, was a major trend that Putin aimed to reverse. Pro-Western Atlanticists, many of whom populated the Yeltsin administration, were gradually delegitimized by their opponents, especially Eurasianists, for allowing this to occur. The replacement of Andrei Kozyrev, a pro-Western Foreign Minister, by the less liberal Yevgeny Primakov was widely viewed as an acknowledgment by Yeltsin that Russia had been "playing a weak hand." 56 The appointment of Primakov was more pragmatic than many of Yeltsin's opponents would have liked, especially since it was Primakov himself who ultimately acquiesced and signed the founding act with NATO. This was the historical backdrop when

\footnotetext{
${ }^{52}$ Dimitry Zaks, "Yeltsin Assures Russia Nothing Lost to NATO," The Moscow Times, May 20, 1997, $<$ http://www.themoscowtimes.com/news/article/yeltsin-assures-russia-nothing-lost-tonato/307070.html\#ixzz25iuZgCS5> (Accessed July 29, 2012).

${ }^{53}$ Thomas Friedman, "Not Yet," The New York Times, March 24, 1997, <http://www.nytimes.com/1997/03/24/opinion/not-yet.html?src=pm> (Accessed July 17, 2012).

${ }^{54}$ Ian MacWilliam, "Summit to Ease NATO-Russia Strain,” The Moscow Times, March 15, 1997, $<$ http://www.themoscowtimes.com/news/article/summit-to-ease-nato-russiastrain/310298.html\#ixzz25ivqRPTr> (Accessed July 19, 2012).

${ }^{55}$ Dimitry Zaks, "Yeltsin Assures Russia Nothing Lost to NATO,” The Moscow Times, May 20, 1997, $<$ http://www.themoscowtimes.com/news/article/yeltsin-assures-russia-nothing-lost-tonato/307070.html\#ixzz25ix8MnRJ> (Accessed July 19 2012).

${ }^{56}$ Michael R. Gordon, "Russia Agrees to NATO Plan Pushed by Clinton to Admit Nations From Eastern Bloc," The New York Times, May 15, 1997, < http://www.nytimes.com/1997/05/15/world/russia-agrees-to-nato-planpushed-by-clinton-to-admit-nations-from-eastern-bloc.html?pagewanted=all\&src=pm> (Accessed June 15, 2012).
} 
Putin first became president. It was because of this historical context that the overarching objective of the next administration was to regain lost Russian prestige and power and make a clear break with the previous regime. Yeltsin's tenure as President of the Russian Federation, along with Western opportunism, was thus instrumental in creating a fertile environment for an alternative vision for Russian foreign policy. After Yeltsin's abrupt resignation, Putin would take office at a time when cooperation with the West was widely viewed within Russia as untenable politically and most importantly not wholly within the scope of Russia's interests.

\section{Early Stages of Putin's Presidency}

When Vladimir Putin took office in 2000 he commissioned the drafting of a new Russian foreign policy concept (RFPC). In this document Russia viewed itself "as one of the largest Eurasian powers" whose primary objective was to "achieve a multi-polar system of international relations that really reflects the diversity of the modem world with its great variety of interests." ${ }^{57}$ Putin's most important statement of purpose for the guiding principles of his foreign policy approach was Eurasianist in nature. This foreign policy concept not only viewed Russia as a major 'Eurasian power', but also rejected the "growing trend towards the establishment of a unipolar structure of the world with the economic and power domination of the United States." 58 The rejection of Western unilateralism, which it viewed as 'destabilizing', along with its promotion of a multipolar alternative were clear indications of a more assertive Russian foreign policy. It would no longer allow the United States and its Western powers to dictate the conditions of the international system. Instead Russia sought to promote the use of international institutions such as the U.N. and increased respect for international law as the primary framework of its multipolar system.

The National Security Concept (NSC), published the same year, also illustrated Russia's growing frustration with the current system of international relations. For the Putin administration the previous decade had been characterized by the West taking advantage of a weakened Russian Federation. As the document notes many states continued to "weaken Russia's positions in the political, economic, military and other spheres. The attempts to ignore the interests of Russia when tackling major problems of international relations . . . undermine international security and stability ..."59 This was a departure from the Yeltsin

\footnotetext{
${ }^{57}$ Putin, “The Foreign Policy Concept of the Russian Federation,” (2000).

${ }^{58}$ Ibid.

${ }^{59}$ Vladimir Putin, "National Security Concept of the Russian Federation," Ministry of Foreign Affairs of the Russian Federation (January 10, 2000), < http://www.mid.ru/bdomp/ns-
} 
administration's more conciliatory tone with the West. Above all, it was the beginning of Russia's reassertion of its role as an important player in the international system. To this end Putin's government declared that Russia would "facilitate the development of an ideology of the creation of a multipolar world ..."60 The placement of this declaration, as a top priority among Russia's national interests, demonstrated that Putin had seen the disadvantages to the previous decade's ideological confusion. Without an overarching doctrine to guide its foreign policy, Russia felt it had been taken advantage of. The creation of such a doctrine was therefore of critical importance to Putin and his administration. Both of these documents provided a clear account of the nascent stages of this process. These initial declarations point to a set of guiding principles that were becoming increasingly Eurasianist in nature.

However, it should be noted that at this stage in Putin's first term, Russia was not completely hostile to the idea of cooperation with the West. On numerous occasions these documents claimed that it was in Russia's interest to cooperate, in many areas, with its Western counterparts. The departure from previous policy was that this cooperation ought to be done on more 'equal' terms. Russia sought respect from potential partners and, if such overtures were made, Russia would respond in kind. This reciprocal logic would come to characterize much of Russia's foreign policy after 2000. As the NSC stressed, Russia sought "equitable and mutually beneficial cooperation . . . with the leading countries of the world."61 The RFPC even offered a tentative olive branch to NATO stating that "The intensity of cooperation with NATO will depend on its compliance with key clauses of this document ..." and would only be possible. . . if it is based on the foundation of a due respect ..."62 Clearly, Russia was open to cooperation with the West if ira interests were taken into consideration. If the West did so it would inherently reestablish Russia's status as a great power- a cornerstone of contemporary Russian foreign policy and a key tenet of Geopolitical Eurasianism. The character of Russia's foreign policy at this point was therefore highly reactionary. The course it would take over the next decade was, to a large extent, dependent on how the West treated Russia and how this treatment would be perceived in Moscow.

Russian willingness to cooperate with the West was not merely empty diplomatic rhetoric. The terrorist attacks on September 11, 2001 against the United States gave the first and perhaps greatest opportunity to put this to the test. Putin was the first foreign official to

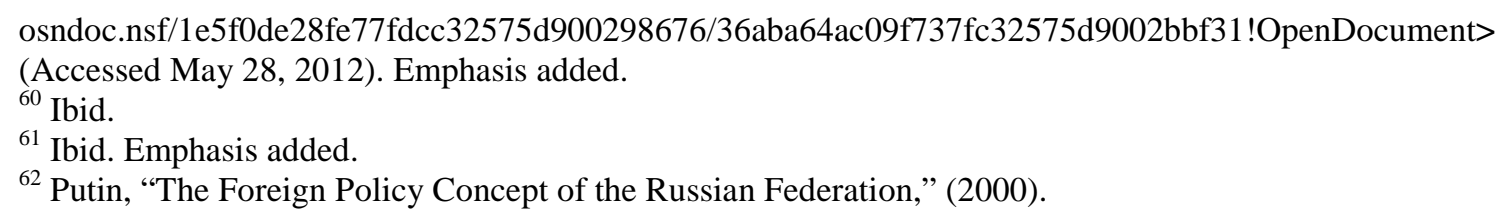

${ }^{62}$ Putin, "The Foreign Policy Concept of the Russian Federation," (2000). 
call President Bush following the attacks. In a televised address to Russia the next day Putin gave a statement of conditional support that was in line with both the RFPC and the NSC stating that:

"We believe that, first of all, attention must be paid to strengthening the role of those international institutions that were created to strengthen international security ... It is also necessary to energetically work on perfecting the international legal base to allow timely and efficient reaction to terrorist attacks." ${ }^{63}$

Russia was willing to support an American invasion of Afghanistan, a state in the strategically important region of Central Asia, as long as the US respected international institutions and upheld the legal basis for doing so. Putin saw this as an opportunity that could be used to dampen international condemnation of its own harsh responses to Chechen terrorists, while also giving his country leverage in future dealings with the West. In his eyes the Americans would be indebted for Russian help and this act of good faith could be redeemed when needed in the future. Russian assistance in the US response to these attacks was more than symbolic and required a tremendous increase in US and NATO presence in Central Asia - an area that Russia had traditionally viewed as its 'near abroad' and a 'privileged sphere of influence'. Russian cooperation was thus defined by Putin in practical terms: 1) intelligence sharing, 2) use of Russian airspace, 3) diplomatic assistance with Afghanistan's Central Asian neighbors, and 4) military and humanitarian aid to the Afghan government. ${ }^{64}$

Putin's statement also left open the possibility of deeper cooperation which he said was contingent on the 'quality' and 'mutual understanding' between Russia and the US. Even when the Taliban in Afghanistan had approached Moscow in an effort to garner its support and give Russia the opportunity to do to the US what the Americans had done to them in the 1980s, the Defense Minister Sergei Ivanov at the time evocatively responded with the "universal English term: F*** off." $65^{*}$ The importance of this support indicated that early in Putin's Presidency, Russia was still open to cooperation with the West, if it were treated as an equal partner. Moreover, this cooperation demonstrated that at this stage in Putin's presidency Russian foreign policy was not entirely devoted to the Geopolitical Eurasianist doctrine. It still allowed for large geopolitical concessions enabling a tremendous US and Western-led military presence in Central Asia. Such a situation, from a geopolitical

\footnotetext{
63 “A Nation Challenged; In Putin's Words: 'Ready to Contribute'," The New York Times, September 25, 2001, <http://www.nytimes.com/2001/09/25/world/a-nation-challenged-in-putin-s-words-ready-to-contribute.html> (Accessed June 2, 2012). Emphasis added.

${ }^{64}$ Ibid.

${ }^{65}$ Putin, Russia, and the West: Taking Control. DVD, dir. British Broadcasting Company (January 19, 2012; London: BBC Two), 29:01.
} 
standpoint, is not advantageous to Russia as it permits a competitor to infringe on an area that Russia has deemed an area of strategic importance.

The key to understanding the development of Russian foreign policy during the first few years of Putin's presidency is how a wide array of Western actions were perceived in Moscow. Early in 2001, Sergei Ivanov, then Putin's national security advisor, warned that potential NATO expansion "will create a fundamentally new situation in Europe that objectively infringes on Russia's political and military interests. This could lead to a serious crisis." ${ }^{66}$ Obviously already highly suspicious of NATO enlargement during the 1990s, Russia became incensed as the military alliance grew closer to its borders. The inclusion of the Baltic States into NATO was a particularly important turning point in Russia's attitude towards the West. The RFPC was emphatic that "NATO's present-day political and military guidelines do not coincide with security interests of the Russian Federation." ${ }^{67}$ Moreover, the NSC reiterated its 'negative' attitude towards the expansion of the alliance and saw the "eastward enlargement of NATO" as a main threat to its national security. ${ }^{68}$ Despite these criticisms, the United States and its allies moved forward with the alliance's single largest expansion in the post-Soviet era, incorporating three former Soviet republics (Estonia, Latvia, Lithuania), three previous Warsaw Pact members (Bulgaria, Romania, Slovakia), along with Slovenia. Additionally, Georgia and Ukraine were granted 'Membership Action Plans" (MAP) which included language guaranteeing both states membership at a to-be-determined date. Russia's deep concerns about NATO's expansion were clearly not being heard in the West. Even the continued existence of the alliance troubled Russian policy-makers. With the Warsaw Pact dissolved and the Cold War ended, what exactly was the purpose of NATO's continued presence in Europe? As Putin said in a 2005 interview, "expanding NATO will not answer the challenges of the present day ... There are many other questions to which there are no answers." ${ }^{69}$ These unanswered questions permeated Russian strategic thinking and fed Moscow's suspicions of the West's true intentions.

The United State's campaign to install a missile defense shield in Europe tremendously hampered Russia's willingness to cooperate with the West as well. On December $13^{\text {th }}, 2001$, months after profound Russian overtures of cooperation with the United

\footnotetext{
${ }^{66}$ Steven Erlanger, “The World; Learning to Fear Putin's Gaze,” The New York Times, February 25, 2001, $<$ http://www.nytimes.com/2001/02/25/weekinreview/the-world-learning-to-fear-putin-sgaze.html?pagewanted=all\&src=pm> (Accessed June 12, 2012).

${ }^{67}$ Putin, "The Foreign Policy Concept of the Russian Federation," (2000).

${ }^{68}$ Putin, "National Security Concept of the Russian Federation," (2000).

${ }^{69}$ Vladimir Putin, "Interview with Radio Slovensko and the Slovakian Television Channel STV," Radio Slovensko (February 22, 2005), <http://archive.kremlin.ru/eng/speeches/2005/02/22/2038_type82916_84445.shtml> (Accessed May 15, 2012).
} 
States, George W. Bush officially announced that the US would withdraw from the AntiBallistic Missile Treaty which had been in effect since 1972. The unilateral American withdrawal from the treaty greatly angered Moscow, but was somewhat mitigated with the successful negotiation of 'SORT', a strategic arms reduction treaty. ${ }^{70}$ Still this began the antagonistic campaign of the Bush administration to install a comprehensive missile defense system with facilities in the Czech Republic and Poland. It would become one of the most contentious issues in US-Russian relations over the course of Putin's first two terms as President. The United States consistently claimed that the shield was intended to protect itself, its European allies, and even Russia from nuclear attacks by 'rogue states' such as Iran. Yet, Russia had a dim view on the planned installations and saw it as a destabilizing force which undermined its nuclear strike capabilities. Russian suspicions were understandably high especially after the Clinton administration, the previous year, rejected Putin's offer to pool Russian and American resources together to create a joint missile defense shield ${ }^{71}$ — an offer that was rebuffed by the Americans twice more by subsequent administrations. Russia even joined with China in denouncing the plan. They issued a joint statement that argued, "Implementing this plan will have the most grave, adverse consequences, not only for the security of Russia, China and other countries, but also for the security of the U.S. and global strategic stability."72 This statement is a clear indication of Russia's growing frustration with the West and its willingness to create alternative alliances, with non-traditional partners such as China, to oppose what it viewed as mounting Western unilateralism.

The US-led invasion of Iraq provided yet another example to Russia that the West would continue to pursue a foreign policy that disenfranchised Russia or at the very least ignored or did not consider its interests. Despite Russia's vocal criticisms, motivated to an extent by its economic interests in Iraq, and the use of its veto power as a member of the UN Security Council to try and prevent military intervention, the US-led coalition invaded Iraq. Putin denounced the invasion saying that it was done "contrary to the world public opinion, contrary to the principles and norms of international law and the Charter of the UN" and

\footnotetext{
${ }^{70}$ It should be noted that the Strategic Offensive Reductions Treaty (SORT) was a rather hollow victory for both parties. Its primary reason for existence was to save face for both sides. Unlike previous arms reductions treaties, SORT lacked a mechanism for verification, had no schedule for reductions, and did not require warheads to be disassembled.

71 "Putin proposes joint Russian-U.S. missile defence shield project," Deutsche Presse-Agentur, June 2, 2000, < www.lexisnexis.com/hottopics/lnacademic> (Accessed June 7, 2012).

${ }^{72}$ Miro Cernetig, "Russia, China agree to historic partnership," The Globe and Mail, July 19, 2000,

<http://www.jjvanka.net/archief/balkan_2000/3---/globe023.html> (Accessed June 10, 2012).
} 
created a "threat of the disintegration of the established system of international security . .,"73 Without a doubt Russia was slowly losing patience with what it perceived to be unilateral Western actions predominately led by the United Sates. This would become a recurrent pattern in Russian-Western relations. Despite significant Russian concessions, they were continuously rebuffed by the trans-Atlantic powers, especially during the Bush administration. The most obvious example being the Iraq invasion and the subsequent rift it created in Russia's willingness to collaborate with the West on a variety of issues, specifically nuclear non-proliferation. For instance when the invasion seemed imminent, Russia resolved to forge ahead with its previous $\$ 800$ million investment in Iran's Bushehr Nuclear Power Plant, agreeing to construct two additional reactors at the site, despite heavy pressure from the US and the EU. ${ }^{74}$ Although Western pressure was successful in delaying Russia's support to Iran, the nuclear facility nonetheless received fuel shipments from Russia starting in 2006. The facility became fully operational in 2011 and has been a glaring example of Russian defiance of the West - the roots of which can be traced back to Iraq. For Putin, if Russia's interests were not to be taken into consideration in Iraq, they would ensure he would have to be in Iran.

Russia increasingly felt that the country was being surrounded. They viewed NATO's enlargement as an extremely antagonistic gesture. Simultaneously, 'colored revolutions' throughout the former Soviet space were sweeping pro-Western governments into office. As the Russian Foreign Minister Sergey Lavrov explained, "We see political provocations, various kinds of 'revolutions,' the cynical practice of double standards being brought into play." 75 The Rose Revolution in Georgia (2003), the Orange Revolution in Ukraine (2004), and the Tulip Revolution in Kyrgyzstan the following year all fed Russia's growing concern with the West's increased presence on its borders. Asked about these revolutions in an interview, Putin maintained that they wanted an equitable partnership with whichever governments were in power there, but also that Russia still had “ interests in these countries,

\footnotetext{
${ }^{73}$ Vladimir Putin, "Statement on Iraq at Kremlin Meeting," The Kremlin (March 20, 2003), <http://archive.kremlin.ru/eng/text/speeches/2003/03/20/0000_type82912type82913_44225.shtml> (Accessed June 10, 2012).

${ }^{74}$ House Committee on International Relations, Celeste A. Wallander Testimony for Russia's Policies toward the Axis of Evil: Money and Geopolitics in Iraq and Iran, $108^{\text {th }}$ Cong., $1^{\text {st }}$ sess., February 26, 2003, <http://www.globalsecurity.org/military/library/congress/2003_hr/wall0226.htm> (Accessed June 12, 2012). ${ }^{75}$ Sergey Lavrov, “Speech by Russian Minister of Foreign Affairs Sergey Lavrov at the Foreign Ministry's MGIMO University on the Occasion of the New Academic Year" (MGIMO University, Moscow, September 1, 2008), <http://www.mid.ru/bdomp/brp_4.nsf/e78a48070f128a7b43256999005bcbb3/d2ca87d862a0db6dc32574b9001d 9be5!OpenDocument> (Accessed August 14, 2012).
} 
and in other countries, as we say, in countries of the near and far abroad."76 Undoubtedly Russia still saw these states, as well as other former Soviet bloc countries, as a contiguous area of Russian influence. Encroachment by outside states, specifically Western powers, was seen as a direct affront to Russian power. This was again exemplified when Russia accused Western NGOs of unduly supporting these movements. ${ }^{77}$ Russia also mounted a serious effort to undermine or reverse these trends. ${ }^{78}$ Putin himself was extremely critical of these revolutions and at one point even insinuated that the next one would be 'blue' - in Russia rose and blue are the colors of the gay rights movement. ${ }^{79}$ Taking a more diplomatic tone, he called the revolutions a "well-tested scheme for destabilizing society. I do not think it appeared by itself." ${ }^{80}$ Clearly Russia felt that its interests were not being taken into consideration. Despite Russian protests and official declarations, NATO expansion continued along with what they saw as even more pernicious - the installation of Western-oriented governments in the former Soviet space.

During the early years of Putin's presidency and up through his second term, Russia had not been overtly anti-Western. Instead it was increasingly asserting a non-Western identity by opposing key political proposals by the West as evidenced by Iraq. Starting from 2000 they formed their foreign policy around the Eurasianist notion that Russia should be respected once more as a great power regardless of Western approval. The official language of the National Security Concept (NSC) of 2000 clearly stated that Russia's overriding national interest boiled down to "ensuring the sovereignty and reinforcing the position of Russia as a great power and one of the influential centres [sic] of the multipolar world ..."81 Moreover, the Russian Foreign Policy Concept (RFPC) of the same year began from the position that all policy must be "fully consistent with the interests of the Russian Federation

\footnotetext{
${ }^{76}$ Putin, "Interview with Radio Slovensko."

${ }^{77}$ Jonathan Steele, "Putin Still bitter over orange revolution," The Guardian, September 6, 2005, <http://www.guardian.co.uk/world/2005/sep/06/russia.jonathansteele> (Accessed June 19, 2012). This accusation was not inaccurate. For instance the Rose Revolution in Georgia was helped along by Western aid and media. For a full account of this see: David Anable, "The Role of Georgia's Media—and Western Aidin the Rose Revolution," Joan Shorenstein Center on the Press, Politics and Public Policy (Fall 2005). <http://shorensteincenter.org/wp-content/uploads/2012/03/2006_03_anable.pdf> (Accessed June 10, 2012).

${ }^{78}$ Russia has been variously accused of being involved with the poisoning of Viktor Yanukovych, supporting the Kyrgyzstani revolution that ousted Kurmanbek Bakiyev in 2010, and most famously for its military campaign against Georgia in 2008 which sought to undermine Mikheil Saakashvili's pro-Western regime.

79 "Polish head rejects Putin attack," BBC News, December 24, 2004, <http://news.bbc.co.uk/2/hi/europe/4122721.stm> (Accessed June 14, 2012).

${ }^{80}$ Interfax-Ukraine, "Putin calls 'color revolutions' an instrument of destabilization," Kyiv Post, December 15, 2011, <http://www.kyivpost.com/content/russia-and-former-soviet-union/putin-calls-color-revolutions-aninstrument-of-des.html> (Accessed June 10, 2012).

${ }^{81}$ Putin, "National Security Concept of the Russian Federation," (2000).
} 
as a great power .. ."82 However, despite Russian assertion of its great power status and the creation of a multipolar international system, core Geopolitical Eurasianist tenets were not formulated under a zero-sum logic where Russia was inherently at odds with the West. Instead Russia sought continued cooperation with the West in areas such as anti-terrorism, non-proliferation, and trade. Only after a series of provocative actions by the West including the continued expansion of NATO, real and perceived Western support for pro-Western revolutions in the post-Soviet space, pursuit of a missile defense shield in Europe, and the invasion of Iraq contributed to Russia's foreign policy becoming increasingly more Eurasianist in policy, practice, and rhetoric. Moscow viewed these series of events as antagonistic in nature and began to change its formally conciliatory stance into a more assertive one.

A clear turning point in the nature of Russian Foreign Policy was evident in 2007 with Putin's now well-known speech in Munich. The Russian President forcefully declared that "the United States, has overstepped its national borders in every way." 83 Putin articulated the growing Russian view that the West had overstepped its authority in unilaterally dictating the security environment of the international system via the EU and NATO and denounced the West's refutation of international law and norms. By delineating a more assertive course for Russian foreign policy he justified it in light of the West's pursuit of a missile defense system which would 'undoubtedly create an arms race in Europe' while also questioning the growth of NATO. Declaring that NATO expansion "represents a serious provocation that reduces the level of mutual trust" he also rhetorically asked who this expansion was truly aimed at - a thinly veiled remark which revealed that Russia saw itself as NATO's true target. ${ }^{84}$ Reinforcing this point, Putin complained of earlier promises made by NATO not to expand, "guarantees that were made and that are not being observed today." 85 Additionally, Putin reiterated Russia's negative view of the influence of Western NGOs in the post-Soviet space stating that "it is clear for all, that when these non-governmental organisations [sic] are financed by foreign governments, we see them as an instrument that foreign states use to carry out their Russian policies. ${ }^{, 86}$ Nearly every dimension of this speech was a listing of perceived

\footnotetext{
${ }^{82}$ Putin, "The Foreign Policy Concept of the Russian Federation," (2000).

${ }^{83}$ Vladimir Putin, "Speech and the Following Discussion at the Munich Conference on Security Policy" (Munich February 10, 2007).

<http://archive.kremlin.ru/eng/speeches/2007/02/10/0138_type82912type82914type82917type84779_118123.sht $\mathrm{ml}>$ (Accessed June 24, 2012).

${ }^{84}$ Ibid.

${ }^{85}$ Ibid.

${ }^{86}$ Ibid.
} 
Western actions and wrongs at the expense of Russia and other states who sought to promote a 'multipolar' system.

Putin voiced Russia's growing attitude that its attempts to collaborate with Western institutions had been rebuffed and that the trans-Atlantic powers had begun to "impose new dividing lines and walls on us ... ones that cut through our continent." ${ }^{, 87}$ Russia's view that it had been effectively rebuffed as a potential partner of the West, by the West's own actions, was an oft-repeated theme. This argument also illustrated the Russian outlook that it had been increasingly isolated from the West. The logical alternative to such a position would be to look for partnerships elsewhere, a key conclusion for the doctrine of Geopolitical Eurasianism. Another example of Russia's forthcoming foreign policy logic came when Putin declared that "the system of international relations is just like mathematics. There are no personal dimensions" - an allusion to the underlying geopolitical logic of Russian diplomacy. ${ }^{88}$ Russia's disillusionment with the West was becoming readily apparent and laid the groundwork for an alternative foreign policy. This alternative foreign policy would have the imprint of earlier thinking and would ultimately become more fully Eurasianist in time. Putin concluded that Russia would still be open to cooperation, but only on a more equitable basis. Ending on a rather Eurasianist note, Putin emphasized that Russia would 'carry out an independent foreign policy' - indicative of the 'third-way', the doctrine advocated by Geopolitical Eurasianism.

The first two terms of Putin's Presidency were key to later developments in the substance and practice of Russian foreign policy. The first priority of Putin's administration was to make a clear break with the chaotic Yeltsin years and rehabilitate Russia's prestige internationally. Russia's foreign policy started out firm, but was still open to cooperation, especially after the September $11^{\text {th }}$ attacks. This horrific terrorist attack offered a unique area of cooperation between Russia and the United States in the area of anti-terrorism. Yet, a series of controversial actions undertaken by Western powers (especially the United States), coupled with Russia's unfavorable reaction to them, slowly began a process by which Russian foreign policy evolved. As Fyodor Lukyanov, editor of Russia in Global Affairs recently observed, Putin had become "sincerely anti-American," because of "his experiences with Bush-era America." ${ }^{89}$ Incrementally, Russian foreign policy was becoming more Eurasianist in nature, specifically conforming to the doctrine outlined at the beginning of this chapter. This process

\footnotetext{
${ }^{87}$ Ibid.

${ }^{88}$ Ibid.

89 “Vladimir Putin Steps Out," The Economist, June 16, 2012, <http://www.economist.com/node/21556962> (Accessed June 20, 2012).
} 
became most apparent after Putin gave a speech outlining Russia's growing dissatisfaction with the West and its intended responses to its frustrated relationship with the trans-Atlantic powers. During the course of his powerful speech, Putin also revealed the growing geopolitical logic behind his foreign policy, likening the international system to mathematics, where unbreakable laws governing conduct exist. It foreshadowed Russia's growing diplomatic assertiveness which can best be described as Geopolitical Eurasianism. Consciously or not, Putin's Munich speech in 2007 was a declaration of Eurasianist principles that would come to characterize Russian foreign policy in the following years.

\section{Medvedev: A New Foreign Policy Concept?}

Due to constitutional restrictions, Putin was unable to run for a third consecutive term as President. Instead he supported his Prime Minister Dmitry Medvedev in a bid to take over the presidential reigns in 2008, albeit with the apparent understanding that Mr. Putin would retake the office thereafter. This created a puzzling leadership tandem where it was widely speculated who was truly in charge of the Russian Federation- Putin or the protégé? Ostensibly, it was Medvedev, widely viewed in the West as a liberal reformer, who was in charge. Over the course of his presidency it became readily apparent that Medvedev was not a strict adherent to the Geopolitical Eurasianist doctrine like Putin. As the 2008 war with Georgia would show, Medvedev was a voice of restraint in an increasingly Eurasianist Kremlin. For all intents and purposes however, it would be Prime Minister Putin who truly wielded power behind the scenes. The question was unequivocally put to rest on September 24th, 2011 when Medvedev proposed to the United Russia party congress that Putin should seek a third term as president. However, during Putin's time as Prime Minister Russia would codify many of the proclamations he made while President. During Medvedev's tenure, as required by the Russian constitution, a new foreign policy concept was created. This document would constitute another milestone in the growing Geopolitical Eurasianist character of Russian foreign policy.

In its introduction, the New Russian Foreign Policy Concept of 2008 (NRFCP) saw the international system of competition through a "civilizational dimension which suggests competition between different value systems and development models ..."90 This echoes Samuel Huntington's seminal work, Clash of Civilizations, and is a clear indication that Russia views international relations as a system of competing developmental models which is

\footnotetext{
${ }^{90}$ Dmitry Medvedev, "The Foreign Policy Concept of the Russian Federation," Ministry of Foreign Affairs of the Russian Federation (July 12, 2008), <http://archive.kremlin.ru/eng/text/docs/2008/07/204750.shtml> (Accessed May 28, 2012).
} 
a fundamental tenet of Geopolitical Eurasianism. Russia was also starting to view itself as a main proprietor of a new developmental model since "the cultural and civilizational diversity of the modern world is increasingly in evidence" as a collective "reaction to the prospect of loss by the historic West of its monopoly in global processes." ${ }^{91}$ This declaration demonstrated that Russia was growing more confident in its power status, especially at the expense of the West. The Geopolitical Eurasianist goal of regaining Russia's great power status was coming closer to fruition and the NRFPC reflected this attitude. Moreover, Russia was able to do this despite the West's "continued political and psychological policy of 'containing' Russia ..."92 From the document's opening it articulated a rejection of Western developmental models in favor of what has been famously dubbed 'Sovereign Democracy ${ }^{93}$ — a distinctive 'third way' by which Russia, independent of international opinion or pressure, conducts itself domestically and internationally. The NRFPC also is a primary example of an overall reassertion of Russia's great power status along with the promotion of the 'principles of multilateralism'. Both of these are clear affirmations of the first two tenets of Geopolitical Eurasianism.

Again Russia declared that its relations with the West and especially NATO would be based on the extent to which their policies signified a "readiness for equal partnership, unswerving compliance with the principles and standards of international law. .."94 This seemingly conciliatory language was based on Russia's negative assessment of the West's, especially the United States', perceived unilateralism which Moscow viewed as 'destabilizing'. Indicative of Russia's growing geopolitical logic, the NRFPC stated that this type of unilateral action "provokes tensions and arms race, exacerbates interstate differences," which expands zones of conflict "in the geopolitical area around Russia." 95 This statement alludes to Russia's idea of a 'privileged sphere of influence' in the geographical spaces neighboring Russia which they term their 'near abroad'. Additionally, Russia reiterated its great power ambitions by reaffirming the "geopolitical position of Russia as the largest EuroAsian power, [and] its status as one of the leading States of the world ..." ${ }^{96}$ Clearly the geographical location of Russia, at the heart of the geopolitically important region of Eurasia,

\footnotetext{
${ }^{91}$ Ibid.

92 Ibid.

${ }^{93}$ The term, popularized by Putin's close aide and Deputy Chief of Staff Vladislav Surkov in 2006, has been widely used by Russian policy-makers to describe Russia's distinctive political model that is implemented domestically. More importantly, the concept emphasizes the primacy of the state in all matters and seeks to preserve its independence from undue outside pressure or influence to change.

${ }^{94}$ Medvedev, "The Foreign Policy Concept of the Russian Federation," (2008).

95 Ibid.

96 Ibid.
} 
is an important source of strength and contributes to its ambitions to be an international power. The reassertion of Russia as a leading world power, in an emerging 'multipolar' world (a recurrent theme throughout the text), is undoubtedly undergirded by a particular geopolitical logic. The logic and its foundation are found in the Geopolitical Eurasianist doctrine. Most tellingly, the implementation of Russian foreign policy would be the primary 'instrument' for guaranteeing "steady national development and of ensuring its competitiveness in a globalizing world." ${ }^{97}$ Put another way, a robust foreign policy that can adequately pressure its neighbors - a geopolitical idea of control and expansion of influence over a specific area, region or other geographic space- will result in increased internal stability while improving Russian competiveness. This is an especially salient issue in Russia's southern and eastern regions as mentioned earlier. Evidently, only through the implementation of such a foreign policy can Russian policy-makers maintain control of the vast landmass that is Russia.

\section{The 2008 Russo-Georgian War: Flexing Eurasianist Muscles}

Less than a month after the adoption of the New Russian Foreign Policy Concept of 2008, Russia would be embroiled in a short, but intense conventional war with its neighbor Georgia. This war changed fundamentally the dynamics of Russia's relationship with the West. It has become a major example of Russian foreign policy's increasing adherence to the Geopolitical Eurasianism doctrine. The war itself was an example of Russia's ambition to reassert control over areas in the post-Soviet space and also constituted a declaration of sorts that its interests should and would be heard moving forward. The military action was not just directed at Georgia, but also at the United States, which had been sponsoring Georgia diplomatically and economically since the Rose Revolution brought the pro-Western regime of Mikhail Saakashvili to power. More broadly, the Russo-Georgian War was a message to the West on the whole, that Russia would no longer tolerate what it viewed as a long-term strategy of containment and encirclement. This strategy, strongly alluded to and referenced in the NRFPC, would become one of the underlying factors that spurred Russia's preparation for action leading up to the August war. As former U.S. Deputy Assistant Secretary of State for European Affairs Ronald Asmus noted in his influential book on the conflict, "Moscow was rebelling against a European security architecture ... which from the Kremlin's perspective

${ }^{97}$ Ibid. 
was facilitating a geopolitical shift against it." ${ }^{, 98}$ Establishing an alternative structure, built around the geopolitical notion of spheres of influence, was an overarching goal of Russia's military action. However, it is also incorrect to think of Georgia as solely the victim of Russian aggression - it too was complicit in the conflict, with its quixotic attempt to retake the breakaway enclaves of South Ossetia and Abkhazia being a major catalyst for violence. In reality, Russia had set a trap for Georgia, baiting it to try and forcefully retake the enclaves, so that the Russian military had an ostensible reason for deployment. The Georgian leadership foolishly took the bait and allowed Russia to carry out its most overt Eurasianist action in the post-Soviet era to that date.

Russia's underlying motivations for the war were multifaceted. There was a relationship between NATO's continued expansion, Georgia's aspirations to be part of this expansion, and Russia's negative attitude towards these developments. Asked about NATO granting Membership Action Plans (MAP) to both Georgia and Ukraine at the Bucharest summit in 2008, then Russian Chief of General Staff Yuri Baluyevsky stated, "This is not the end of the day," and that "We will live and see." ${ }^{99}$ Four months before the outbreak of hostilities, he prophetically warned that "Russia will take steps aimed at ensuring its interests along its borders," and that they would be "not only be military steps, but also steps of a different nature." ${ }^{100}$ Russia evidently had had enough with NATO encroachment into what it viewed as its 'near abroad'. Significantly, Russia was willing to risk military action to preserve its interests in this region. Moreover, the recent independence of Kosovo, recognized by many Western governments, was another key factor in the lead-up to war. ${ }^{101}$ Putin declared at a CIS summit meeting after Kosovo's declaration, that the recognition of Kosovo set a, "terrible precedent" and that it was, “. . . a stick with two ends, and one day the other end of this stick will hit them[the West] on their heads." ${ }^{102}$ For Russia there was a direct parallel between Kosovo and the two breakaway enclaves in the Republic of Georgia. This is evidenced by Russia's unilateral and essentially sole recognition of both Abkhazia and South Ossetia as independent states.

\footnotetext{
${ }^{98}$ Ronald D. Asmus, A Little War that Shook the World: Georgia, Russia, and the Future of the West (New York, NY: Palgrave Macmillan, 2010), 218.

99 "Russia army vows steps if Georgia and Ukraine Join Nato," Reuters, April 11, 2008, <http://www.reuters.com/article/2008/04/11/us-russia-nato-steps-idUSL1143027920080411> (Accessed June 10, 2012).

${ }^{100}$ Ibid.

${ }^{101}$ For a good overview of this correlation see: Derek Averre, "From Pristina to Tskhinvali: the legacy of Operation Allied Force in Russia's relations with the West," International Affairs 85 (2009): 575-591.

${ }^{102}$ BBC Worldwide Monitoring, "Kosovo 'Blows Up' International Order, Sets 'Terrible Precedent'Putin,” Channel One TV, February 22, 2008. (Accessed June 10, 2012).
} 
Further insight into Russia's underlying motives for the war was also revealed by Yezhednevny Zhurnal journalist Aleksandr Ryklin. Speculating on a potential rift between Putin and Medvedev on how far to extend the conflict, Ryklin quoted a source close to the administration stating that:

\footnotetext{
"Today we can speak about the serious disagreements between the President and the Prime Minister on further developments in the Caucasus ... The president did not originally intend to go beyond the peacekeeping mission [in South Ossetia], and at some point they began to talk about the 'the logic of the war $^{\text {' }}$ and the unexpected opportunity to resolve 'important geopolitical objectives.",103
}

It is important to note that at the time Ryklin was rather skeptical of these statements and assumed the conflict was brought to an end because of conflicting financial interests close to the Kremlin. However, marking the $4^{\text {th }}$ anniversary of the conflict, a controversial documentary emerged quoting Putin and top Russian Generals. Called the "Lost Day", it confirmed many of the assertions of Ryklin's source. ${ }^{104}$ This documentary represents a concerted effort by Putin and a dedicated Eurasianist coterie within the Kremlin to delegitimize Medvedev, who was evidently hesitant to pursue the Eurasianist objective of total regime change in Tbilisi. The 'logic of the war' and the related 'geopolitical objectives' were unambiguous. They signified that Russia, specifically Putin and the Russian military leadership, sought the total capitulation of Georgia - a move which would have completely supplanted the overtly pro-Western, pro-NATO Georgian regime and been a complete realization of Geopolitical Eurasianist goals. When asked about the documentary after its release, Putin declined to support Medvedev's actions during the war and instead highlighted his own high level of involvement in the conflict, which contradicted and undermined Medvedev's previous account of events. ${ }^{105}$ Putin's tone here was implicitly supportive of General Baluyevsky, who was quoted in documentary as saying that Russia would not have taken military action "until there was a kick from Vladimir Vladimirovich (Putin) in Beijing." 106 It is therefore significant to note that despite Putin and his General's wishes, Medvedev was able to dilute the potency of the Geopolitical Eurasianist doctrine as it was

\footnotetext{
${ }^{103}$ Aleksandr Ryklin, "They Crawled," Yezhednevny Zhurnal, August 13, 2008, <http://ej.ru/?a=note\&id=8309> (Accessed July 20, 2012). Emphasis added.

${ }^{104}$ Gleb Bryanski, "Russian generals attack Medvedev over Georgia war," Reuters, August 8, 2012, <http://www.reuters.com/article/2012/08/08/us-russia-medvedev-war-idUSBRE87713E20120808> (Accessed August 10, 2012). See also: Nikolaus von Twickel, "Medvedev Defends Role in Georgia War," The Moscow Times, August 9, 2012, <http://www.themoscowtimes.com/mobile/article/466373.html> (Accessed August 10, 2012).

${ }^{105}$ Simon Saradzhyan, “Does Medvedev's indecisiveness justify Putin's return?” Global Post, August 17, 2012 , <http://www.globalpost.com/dispatches/globalpost-blogs/commentary/medvedev-russia-putin-YouTube> (Accessed August 19, 2012).

${ }^{106}$ Gleb Bryanski, "Russian generals attack Medvedev over Georgia war,” Reuters, August 8, 2012.
} 
implemented in the Georgian campaign, at least to a point. This was evidenced by Russia's eventual agreement to Sarkozy's six-point ceasefire plan which officially ended the war, although the degree to which Russia implemented some of the requirements varied considerably.

Nevertheless, the Russo-Georgian war constituted a dramatic step forward for Russian foreign policy's increasingly Eurasianist nature. While Medvedev was seemingly able to bring the war to a more abrupt end than Putin and other Geopolitical Eurasianists would have liked (regime change), the then Prime Minister was still able to exert enough pressure on the Russian president to take military action in the first place- a move that was indicative of Russia's emergence as a great power once again. Additionally, it was a declaration that Russia should be respected while also allowing Russia to reassert influence and control over its periphery. This periphery, as Medvedev explicitly stated, are "The countries on our borders . . . [which] . . . are priorities, of course, but our priorities do not end there." ${ }^{107}$ The importance of this 'near abroad' to Russia's increasingly Eurasianist foreign policy was further exemplified by Medvedev's later official statements during and just after the conflict. Echoing the great power ambitions articulated in the Geopolitical Eurasianist doctrine, Medvedev declared at the height of the war that "Russia has historically been a guarantor for the security of the peoples of the Caucasus, and this remains true today." ${ }^{108}$ Russia saw Georgia as part of its 'privileged sphere of influence' and the military action taken, ostensibly to protect Russian citizens, was a move to ensure that Georgia remained beyond a Western security sphere. As the war ended, Medvedev forcefully stated that "there are regions in which Russia has privileged interests. These regions are home to countries with which we share special historical relations." ${ }^{109}$ If Medvedev seemed hesitant to embrace core tenets of Geopolitical Eurasianism during the war itself, he most assuredly was not after its conclusion. The shortlived war in Georgia was therefore undoubtedly an affirmation of such Eurasianist views as it allowed Russia to project its power into an area of such apparent strategic value.

The geopolitical dynamics of the war should again be emphasized. As the Georgian President Mikhail Saakashvili declared during the war, "They [the Russians] need control of energy routes ... They need sea ports. They need transportation infrastructure. And primarily,

\footnotetext{
${ }^{107}$ Dmitri Medvedev, "Interview given by Dmitry Medvedev to Television Channels," Channel One, Rossia, and NTV (August 31, 2008),

<http://archive.kremlin.ru/eng/text/speeches/2008/08/31/1850_type82912type82916_206003.shtml> (Accessed August 12, 2012).

${ }^{108}$ Dimitry Medvedev, "Statement on the Situation in South Ossetia," The Kremlin (August 8, 2008), <http://archive.kremlin.ru/eng/speeches/2008/08/08/1553_type82912type82913_205032.shtml> (Accessed August 20, 2012).

${ }^{109}$ Medvedev, "Interview given by Dmitry Medvedev to Television Channels," 2008. Emphasis added.
} 
they want to get rid of us." ${ }^{110}$ The geopolitical importance of Georgia's location, an important energy transportation hub connecting the resources of the Caspian Sea to the Black Sea, illustrates another motivating factor for Russia's military incursion deep into Georgian territory. Even though Russian troops stopped just short of taking Tbilisi, they nonetheless set about destroying a large amount of important transportation infrastructure and energy supply lines that had been running through Georgian territory. As one scholar observed, "the purpose was clearly to show the vulnerability of Georgia's infrastructure" and that of the "east-west transportation link."111 The 2005 completion of the Baku-Tbilisi-Ceyhan oil pipeline (BTC), which was fortunately left untouched, circumvented Russia entirely and allowed for Caspian energy resources to be transported to the West avoiding Russia entirely. Its construction was a harbinger for a larger trend in the Caucasus region which included the EU-backed Nabucco pipeline. Russia feared this growing trend in the Caspian region as it diminished its importance as a vital hub for transporting energy resources to Europe. As a result, it was in Russia's interest to disrupt this trend as much as possible. In doing so Russia demonstrated a geopolitical logic, supported by its growing dominance of the energy sector, which falls directly within the purview of the Geopolitical Eurasianist doctrine. Maintaining Russia's ability to control its 'near abroad' via control of the energy sector, a vital instrument of Russian power, was thus a geopolitical goal in and of itself and an important feature in Russian foreign policy's increasingly Eurasianist nature.

The global implications of the Russo-Georgian War were also not lost on Russian policy-makers. Speaking a month after the conflict, Russian Foreign Minister Sergey Lavrov stated that Georgia and the West "had decided on testing Russian power for strength. . ."112 Lavrov was again demonstrating Russia's reassertion of its great power status, a core tenet of Geopolitical Eurasianism, by taking this point further: "Russia has returned to the world arena as a responsible state which can stand up for its citizens. If somebody [i.e. the West] was mistaken on that score, then our resolute actions to force Georgia to peace . . . should have dispelled any such doubts." 113 Without a doubt Russia saw the Georgian War as a clear demonstration of its renewed great power status - a central objective of the Geopolitical Eurasianist doctrine. The conflict was also a way for Russia to indirectly halt the continued

\footnotetext{
${ }^{110}$ Anne Barnard, "Georgia and Russia Nearing All-Out War," The New York Times, August 9, 2008, <http://www.nytimes.com/2008/08/10/world/europe/10georgia.html?_r=3\&pagewanted=all> (Accessed August 20, 2012).

${ }^{111}$ Svante E. Cornell, "Pipeline Power: The War in Georgia and the Future of the Caucasian Energy Corridor," Georgetown Journal of International Affairs 10 (Winter 2009): 136. The author lists the many instances where Russian forces deliberately destroyed Georgian infrastructure to achieve this end. ${ }^{112}$ Lavrov, "Speech at MGIMO University," (2008).

113 Ibid.
} 
expansion of NATO and what it perceived as a strategy of 'containment'. The conflict gave Russia the opportunity to maintain control over its strategic energy corridors, which represented a powerful tool in its diplomatic toolbox. Moreover, it allowed Russia to roll-back and subvert, to a certain extent, the series of 'colored revolutions' that had been taking place throughout the post-Soviet space, by delegitimizing a Saakashvili regime that had most epitomized these developments. These achievements were all Eurasianist in nature - it was a reassertion of Russia's great power status, promoted Russia's interests in its 'near abroad', and was done with clear geopolitical logic.

Additionally, the war promoted Russia's perpetual Eurasianist objective of a more 'multipolar' world while promoting an independent foreign policy identical to the 'third way'. Russia's policy-makers, specifically the foreign minister, argued that such a system was being created as a result of the war, which was a "multipolar world in which states are driven by their national interests" and allowed for the emergence of a "new, self-regulatory international system." " fundamental precepts and principles of the Geopolitical Eurasianist doctrine. As the Russian scholar Fyodor Lukyanov correctly observed, Russia saw the widespread condemnation of its actions by Western powers as "more than just a double standard, but as unabashed cynicism beyond the bounds of normal political practice" and was "now inclined not only to reject completely a path determined by Western values, but actually to deny that such values even exist." "115 The vocal condemnation by many leading Western powers was a clear illustration for Russia that its attempts to integrate and ingratiate into existing political and security structures had been not been successful. To Russia, this failure could be directly attributed to what it perceived as a continued pattern of mistreatment and disrespect by the West. Lavrov was particularly instructive in expressing this sentiment when he complained that the West's denunciation of his country demonstrated a subconscious frustration "for the lack of obedience on the part of Russia" — an attitude he argued that led to their "policy of 'containment.",116 At this juncture it was therefore logical for Russia to embrace, more overtly than before, principles of the Geopolitical Eurasianist doctrine which rejected these Western models of development and relations in favor of a distinctly independent course of

\footnotetext{
${ }^{114}$ Ibid.

${ }^{115}$ Fyodor Lukyanov, "Seven Theses Prompted By Russia-Georgia Conflict," Radio Free Europe Radio Liberty $R F E / R E$, August 26, 2008, <http://www.rferl.org/content/Seven_Theses_Prompted_Russia_Georgia_Conflict/1193933.html> (Accessed August 20, 2012).

${ }^{116}$ Lavrov, "Speech at MGIMO University," (2008).
} 
action. The Georgian War should thus be viewed as an attempt to convey this message abroad and also as a hastening of Russia's embrace of the Geopolitical Eurasianist doctrine.

\section{The NSS and Beyond}

After the Russo-Georgian War of 2008 Russian foreign policy began to become more overtly Eurasianist. The following year President Medvedev commissioned a "National Security Strategy of the Russian Federation to 2020” (NSS). Typically, both a Foreign Policy Concept and a National Security Concept are released at approximately the same time. It was therefore unusual that the Russian leadership waited a full year after the 2008 Foreign Policy Concept to release this strategy. The format of the NSS differed slightly from its predecessor in that it was more wide-ranging, encompassing many different aspects of future Russian strategy. This was most probably related to the Georgian War which gave its framers a unique opportunity to incorporate the newly evolved principles of Russian foreign policy that had materialized after the short-lived conflict. The document formally articulated the rhetoric and worldview that the Russian leadership had been developing before, during, and after the conflict as evidenced by the Russian leadership's public statements. Broadly speaking the NSS had three main themes-economic development as a means of accomplishing national security, emphasis on energy resources as a main pillar of Russian strength and an instrument of foreign policy, and most important to this study the promotion of alternative international organizations to more adequately promote Russian interests. Overall the NSS reiterated many of the core principles that Russia had been espousing since 2007, but with a renewed focus on the above mentioned spheres.

The NSS also reflected a far more assertive and self-confident Russia. It argued that over the past decade there had been a "transformation of Russia into a world leader with regards to ... influence over global affairs. ${ }^{117}$ Russia was becoming more confident on the international stage and in its ability to affect real change in it. This was largely motivated by the recent war in Georgia which it saw largely as a success and also by previously booming commodity prices which allowed it to leverage its energy resources for political gain. The Geopolitical Eurasianist objective of reasserting Russia's great power status was beginning to show tangible results. The NSS took note of this stating that Russia had regained its ability to "defend its national interests as a key player within evolving multipolar international

\footnotetext{
${ }^{117}$ Dmitry Medvedev, "National Security Strategy of the Russian Federation to 2020," trans. Alisa Lockwood, Office of the President (May 12, 2009), <http://rustrans. wikidot.com/russia-s-national-security-strategy-to-2020> (Accessed May 12, 2012).
} 
relations." ${ }^{118}$ This also demonstrates Russia's growing confidence in its efforts to create a multipolar international environment, a key objective of Geopolitical Eurasianism. In total the NSS contained statements which reflect Russia's growing certainty that its Eurasianist efforts were beginning to bear fruit. Its formulation of a foreign policy, independent of Western influences or models had "broadened the possibilities for the Russian Federation to reinforce its influence on the world stage." 119

For all of this noticeable self-praise though, Russia still voiced relentless concerns over Western policies and institutions that it perceived to be against Russian interests. For instance, Russia highlighted, "The inadequacy of the current global and regional architecture, oriented (particularly in the Euro-Atlantic region) towards NATO . . .120 It reiterated the importance of international law and norms to resolving global problems and maintained its position that relations with the West and its institutions would be founded on the 'basis of equality'. The NSS specified again Russia's negative attitude towards NATO's "plans to extend the alliance's military infrastructure to Russia's borders," something Russia viewed as 'unacceptable' and which did not "recognise Russia's legal interests . .."121 Despite these denunciations of the West which had, by this point, become common in official Russian foreign policy documents, they reflected Russia's resolve to pursue a foreign policy that was decidedly independent of Western influence or pressure. To this end the NSS began to stress the importance of international organizations and institutions where Russia was able to exert more influence. Rather than trying to influence world processes by doubling down on relationships with the EU or NATO_ organizations that had made it clear to Russia that Russian interests were not their top priority. Instead Russia took the logical step of promoting alternative institutions which took their interests more to heart or at least gave it the opportunity to more readily influence political outcomes, a feat Russia still had a hard time achieving even under the UN which the NSS nevertheless fully supports. Such a strategy enables Russia to more easily control the outcomes of institutional decisions, especially in the cases where it was the leading member of such an organization.

Although the NSS did state its willingness to further develop ties to the EU and NATO specifically, it did so under the usual preconditions of 'mutual respect' and 'equality' - a stipulation which illustrated Russia's serious doubts at the West's readiness to accept such conditions. Conversely, Russia underscored the importance of international institutions where

\footnotetext{
118 Ibid.

${ }^{119}$ Ibid.

${ }^{120}$ Ibid.

${ }^{121}$ Ibid.
} 
it maintained a leading role such as the Commonwealth of Independent States (CIS), Collective Security Treaty Organization (CSTO), Shanghai Cooperation Organization (SCO), and the Eurasian Economic Community (EurAsEC). Increasing bilateral and multilateral relations with CIS countries was "a priority direction of Russian foreign policy" which would support the "potential for regional and subregional integration and coordination among member-states ..." ${ }^{122}$ The NSS also stipulated that the SCO was of 'particular significance' to Russian foreign policy and that "the reinforcement of the political potential of the SCO [constituted] practical steps towards the enhancement of mutual trust and partnership in the Central Asian region." ${ }^{123}$ Clearly, Russia saw great potential in expanding its political, military, and economic role in its 'near abroad' (mainly CIS members), significantly in Central Asia, through increased participation and support of these international institutions. According to the NSS, Russia's preferred avenue for resolving military matters was the CSTO; for economic and political development they would resort to the SCO and EurAsEc with the more wide-ranging membership of the CIS providing a supplementary role for each. The strategy of using international organizations to increase Russia's role and dominance over certain areas it saw as its privileged 'sphere of influence' does not fully constitute a policy of recreating the Soviet Union. However it does echo its great power ambitions which Russian foreign policy has sought to reassert - an objective that falls squarely within the purview of Geopolitical Eurasianism. As Putin tellingly stated as far back as 2004 the CIS member countries were "now working to restore what was lost with the fall of the Soviet Union but are doing it on a new, modern basis." 124 International institutions were thus becoming a powerful tool for Russia to implement its foreign policy. This process, of promoting international institutions as a viable means of legitimizing the state's actions, would become a recurrent theme throughout Medvedev's presidency and an enduring part of its legacy.

Such a strategy is understandable in light of widespread international condemnation of Russia following its war with Georgia. Moreover, promoting alternatives to NATO and the EU marginalize their overall importance when states such as Russia refuse to fully cooperate with them or fully submit to their interests. This evolving strategy would also come to play a central role after Medvedev left the presidency and Putin retook the reigns of executive leadership. Existing international organizational structures, such as the CIS, CSTO, SCO, and EurAsEc presented the unique opportunity to extend Russian influence into its 'near abroad'

\footnotetext{
122 Ibid.

123 Ibid.

124 "Newsline," Radio Free Europe Radio Liberty RFE/RE, June 18, 2004,

<http://www.rferl.org/content/article/1143183.html> (Accessed August 20, 2012).
} 
while simultaneously refocusing Russia's diplomatic efforts to an area the West would have a much more difficult time contesting. Consequently, while the 'reset' in relations between Russia and the West's leading power, the United States, brought about a modest thaw, Russia still pursued this strategy. With Putin's coming third term as president this plan of action would be cemented as a cornerstone of Russian foreign policy. Despite a new US administration and its efforts to repair Russian-Western relations, it would seem that Russia was unwavering in its course to pursue a policy that was decidedly Geopolitical Eurasianist in character.

\section{The Eurasian Union: The Culmination of Geopolitical Eurasianism}

On September 24th, 2011 Prime Minister Vladimir Putin announced, to uproarious applause in United Russia's party congress, that he would again seek the Russian Presidency. This announcement put to rest years of speculation over the peculiar leadership tandem that had materialized since Medvedev had taken office. Nevertheless, Putin's third term would coincide with a period of significant economic distress in the aftermath of the 2008 financial crisis. As Putin noted, the crisis had "forced states to seek new resources for economic growth." ${ }^{25}$ With commodity prices like oil and gas bottoming out, Russia was unable to rely on high energy prices to finance a large portion of government expenditures. ${ }^{126}$ This put added pressure on Putin, in the face of a continued decline in population, to spur economic growth and development among a Russian population which had increasingly grown accustomed to higher living standards. In the past, Putin would have sought further economic integration with the West and its existing institutions.

To an extent this has remained true, with Russia's recent admittance into the World Trade Organization (WTO) on August 22, 2012. However, this was mainly the result of a long-term negotiation that preceded Putin's leadership. The 18-year negotiation process demonstrated to Russia the West's reluctance to fully integrate one of the world's largest industrialized economies. This reluctance was reinforced by the United States' failure to repeal the Cold War era Jackson-Vanik amendment without preconditions. The failure to exempt Russia from this amendment was due, in large part, to the US Congress' insistence that the 'Magnitsky bill' be passed alongside such an exemption. This action would freeze

\footnotetext{
${ }^{125}$ Vladimir Putin, "A new integration project for Eurasia: The future in the making," Izvestia, October 4, 2011, <http://rusemb.org.uk/press/246> (Accessed October 5, 2011).

${ }^{126}$ Russian government expenditures require Brent Crude prices to stay at $\$ 117$ a barrel or higher. When the global price drops below this point, the Russian government is running a deficit. In the aftermath of the global financial crisis in 2008, Brent Crude fell to below $\$ 40$ a barrel in 2009, putting tremendous financial pressure on the Russian government. Prices this year have regained their pre-2008 levels, but still fluctuate considerably.
} 
the assets and impose visa restrictions on a significant portion of the Russian political elite. Deputy Foreign Minister Sergei Ryabkov expressed Russian sentiments on this matter by insisting, "The last thing we want is for the anti-Soviet Jackson-Vanik amendment to be replaced with anti-Russian legislation." ${ }^{127}$ Putin's third term in office was thus faced with the task of spurring economic development, a goal which the NSS insisted furthered Russian national security, in an environment which required innovative policy thinking independent of the West.

In light of this, a revealing statement of purpose for the future of Russian foreign policy was made a week after Putin's presidential bid announcement on the pages of the Russian newspaper Izvestiya. On October 4th, 2011 Putin put forth his vision for the future trajectory of his state - a "Eurasian Union"- a proposed supranational entity that would build upon the foundations of the Eurasian Economic Community (EurAsEc) and increase the political and economic integration and ties between Russia, Belarus and Kazakhstan. This gradual integration is oddly similar to the arduous process of European integration started with European Coal and Steel Community (ECSC) - a comparison that Putin emphasized enthusiastically throughout his piece. Nevertheless, this announcement illustrated a new path and is evidence of the dominating role Geopolitical Eurasianism has taken within the context of Russian foreign policy. As Putin stated, “. . . deepening the integration process in the CIS is the core of our foreign policy and is our strategic objective." ${ }^{, 128}$ Putin's announcement is therefore the culminating event in the incremental process of Russian diplomacy becoming increasingly more Eurasianist. The idea of a Eurasian Union is the result of this process, one that has been highly reactive, but pragmatic nonetheless. Putin's spokesperson, Dmitry Peskov insisted that "The establishment of the Eurasian Union will be one of Putin's main priorities in the coming six years." ${ }^{129}$ Clearly, Eurasian Union is the primary foreign policy objective of the Russian Federation and is an invaluable tool for understanding the character and future trajectory of Moscow's foreign policy.

One of the most enduring issues facing the Russian Federation today revolves around its national sense of self and its attempts to create a prevailing national identity. Since the collapse of the Soviet Union, Russia has struggled to fully articulate where it sees itself in the

\footnotetext{
${ }^{127}$ Richard Solash, "U.S. Senate Panel Votes To Lift Cold War Trade Restrictions On Russia," Radio Free Europe Radio Liberty RFE/RE, July 18, 2012, <http://www.rferl.org/content/russia-jackson-vanik-magnitskysenate-finance-baucus-pntr-moldova/24649497.html> (Accessed July 20, 2012).

${ }^{128}$ Vladimir Putin, "Russia's Foreign Policy Has Always Been Independent and It Will Remain So," Mezhdunarodnaya Zhizn [International Affairs] 4 (2012): 5.

${ }^{129}$ Pavel Felgenhauer, "Putin Prioritizes Rebuilding the Lost Empire," Eurasia Daily Monitor, October 6, 2011, <http://www.jamestown.org/single/?no_cache=1\&tx_ttnews[tt_news]=38495> (Accessed October 12, 2011).
} 
new world order. Is it a 'European' or 'Eurasian' power? Or has it perhaps transcended these categories and tried to create an identity uniquely 'Russian'? These questions have never been fully answered by the Russian political elite or even scholars. Geopolitical Eurasianism seeks to more fully answer these questions and has thus become an appealing doctrine to inform Russian foreign policy. Putin's proposal for a Eurasian Union can and should be viewed through the prism of these vexing questions. The development of such a union is a conscious effort to shift Russian strategic efforts away from unsuccessful cooperation with the West and its institutions such as the EU and NATO and instead refocus its efforts on developing its own alternatives to such institutions. In doing so the Russian Federation, and Putin more specifically, are moving to create a "powerful supranational association capable of becoming one of the poles in the modern world and serving as an efficient bridge between Europe and the dynamic Asia-Pacific region." 130 This assertion is evidence of a shift toward a Geopolitical Eurasianist doctrine and conveys the importance of Russia's geopolitical presence in Eurasia as a vital bridge between two 'worlds' while also promoting itself as a power pole in an emergent multipolar international system. As a result, the Eurasian Union is an embrace of a more Eurasianist Russian identity, whose interests lie more with its 'near abroad' rather than with further collaboration with the West.

This is an unambiguous shift away from the ad hoc approach frequently taken over the past decade in which Russian identity was manufactured for the specific situation. This protean strategy is best exemplified in some of Russia's more important bilateral relationships as well as its various multilateral relationships. In 2000, for instance, Putin spoke to the Asia Pacific Economic Cooperation group (APEC) and declared that, "Russia always felt itself a Eurasian country." 131 Yet, speaking to the Federal Assembly a few years later he insisted that Russia "was, is, and always will be a leading European nation." ${ }^{132}$ Obviously, Russian national identity has been used as a diplomatic tool in courting various international relationships. As these statements suggest, the Russian leadership has sought to emphasize the multiethnic character of Russia for political gain on many occasions. This represents a core principle in this particular Eurasianist doctrine and an underlying geopolitical logic which informs it. Such an approach did not hamper it diplomatically. It was instead used to Russia's benefit to create diplomatically advantageous images of itself predicated on the most pressing geopolitical concerns for each particular situation. When speaking to audiences in the east, the

\footnotetext{
${ }^{130}$ Putin, "A new integration project for Eurasia," Izvestia, (2011).

${ }^{131}$ Matthew Schmidt, “Is Putin Pursuing a Policy of Eurasianism?', Demokratizatsiya, 13 (Winter 2005): 92.

132 Mankoff, Russian Foreign Policy, 79.
} 
Russian leadership, as Putin did above, stressed Russia's Eurasian heritage, and its European roots when speaking in the West. While this was seen as an innovative tactic, it has been largely ineffective in furthering Russian national interests. The unsuccessful engagements with the EU and especially NATO, analyzed earlier in this chapter, have illustrated to Putin and the rest of Russia's foreign policy establishment that a reappraisal of Russian national interests was needed, including a reassessment as to where and with whom they lie. In short, the Eurasian Union can be understood as a collective realization that Russian interests will be furthered more by refocusing its diplomatic efforts on non-Western areas, specifically Central and East Asia— a distinctly Eurasianist proposition.

The strategy outlined above stems from Putin's critical observation that "Russia's image abroad is formed not by us and as a result it is often distorted and does not reflect the real situation in our country ..." ${ }^{, 133}$ Projecting a positive image of Russia, one that was more palatable for potential partners, was a crucial foreign policy objective. The Eurasian Union helps create a more positive image of Russia abroad, one that looks like an attractive partner for such an integration project. Moreover, this image is predicated on the idea of a multiethnic state that traces its roots to the Soviet Union and embraces the powerful global status of Russia that came with it. In his proposal Putin even acknowledges this legacy as beneficial stating, "We inherited a great deal from the Soviet Union . . . [and] are all interested in harnessing this resource for development." ${ }^{134}$ Speaking negatively about the demise of the Soviet state and about the Eurasian Union more generally, Medvedev declared that "We are working now to unite on a new basis, and I am certain that this union will have a very good future." ${ }^{135}$ Bringing this conception full-circle, Medvedev continued, "We should not be shy when bringing back the ideas of ethnic unity. Yes, we are all different but we have common values and a desire to live in a single big state." 136 These statements reflect a collective desire to reassert Russia's great power status, based on a supranational integration project, which emphasizes the multiethnic character of such a state. As Kirill Barsky, Russia's Representative to the Shanghai Cooperation Organization (SCO), specified, "The affinity between the peoples of Russia and Central Asia, having lived in a single state for almost a century and a half, is self-evident." 137 The Russian objective of reasserting itself as a great

\footnotetext{
${ }^{133}$ Putin, "Russia's Foreign Policy Has Always Been Independent and It Will Remain So," 7.

${ }^{134}$ Putin, "A new integration project for Eurasia," Izvestia, (2011).

${ }^{135}$ Gleb Bryanski, "Putin, Medvedev praise values of Soviet Union," Reuters, November 17, 2011 , $<$ http://in.reuters.com/article/2011/11/17/idINIndia-60590820111117> (Accessed January 13, 2012). 136 Ibid.

${ }^{137}$ Kirill Barsky, "Central Asia Under the SCO's 'Impermeable Umbrella,"” Mezhdunarodnaya Zhizn [International Affairs] 4 (2012): 158.
} 
power via this integration project, based on a multiethnic conception of statehood, is a clear demonstration of the Geopolitical Eurasianist doctrine. Moreover, by expanding Russia's influence into neighboring countries through this process, it asserts the geopolitical idea of a 'privileged sphere of influence' centered around the post-Soviet space.

From its conception, the founders of the Eurasian Union understood the impact such an integration project could have on reversing demographic trends in economically stagnant areas. Siberia and Russia's Far East have had a hard time attracting a native labor force willing to live and work in these areas since the collapse of the Soviet Union. As a consequence, Russia has needed migrant labor to extract the abundant natural resources in these areas. This influx of foreign labor has raised concerns among Russian policy-makers, over their ability to maintain control over territory where Russian citizens are vastly outnumbered over great stretches of space. The creation of a Eurasian Union would diminish the quantity of Chinese migrants coming to Russia because Belarusians and Kazakhs would be able to live and work inside Russia, visa-free, making them an economically viable alternative. As Putin averred, "I believe that our participation in the integration processes underway in this region will boost socioeconomic growth in Siberia and the Russian Far East." 138 These areas have, over the past decade, been magnets for migrant labor especially from China. Such migration has been encouraged by China's bordering provinces having a "population density 62 times greater than the Russian Far East."139 Put another way, China has an abundance of unused labor, while Russia has experienced a shortage. Russian concerns are further intensified by a demographic forecast predicating a decline in the overall population of the region from 6.7 million in 2009 to 4.5 million by $2015 .{ }^{140}$ This has increased Russian anxiety over its ability to maintain control over these areas in the face of a rapidly rising China.

Putin's aspiration, for increased economic development, is based on a model that is wholly separate from the West. Though it is based on the European Union's experience, it is a model that refocuses such efforts into a project that is distinctly independent from Western institutions - a central principle of the Geopolitical Eurasianist doctrine. Additionally, the embrace of a multiethnic Russia within such an institution, hedges against the dilution of Russia's population in such areas. Moreover, the expansion of this integration project furthers

\footnotetext{
${ }^{138}$ Putin, "Russia's Foreign Policy Has Always Been Independent and It Will Remain So," 5.

${ }^{139}$ David Blair, "Why the restless Chinese are warming to Russia's frozen east," The Telegraph, July 16, 2009, <http://www.telegraph.co.uk/comment/5845646/Why-the-restless-Chinese-are-warming-to-Russias-frozeneast.html> (Accessed August 7, 2012).

${ }^{140}$ Ibid.
} 
Russian influence over its periphery as well as inside its own borders. As one scholar noted, the creation of a Eurasian Union would inherently "create new barriers between member states and the outside world. Indeed, limiting the reach of foreign powers-whether of China in Central Asia or the EU in Ukraine-appears to be a major goal of Russia." ${ }^{141}$ Placing Russia at the center of a supranational organization like the Eurasian Union allows for ever greater control over its neighbors, prevents encroachment from outside powers, and further solidifies their grip on existing areas of strategic importance.

Clearly Russia fears Chinese encroachment into Central Asia. As several analysts recently noted, "Russia is far more concerned by growing Chinese influence in [central Asia]. The core of Russia's concerns is the slow but steady progress of the Shanghai Cooperation Organization $[\mathrm{SCO}] \ldots{ }^{\prime 142}$ Over the past few years the SCO has developed into a political entity that China has increasingly used to project soft power throughout the region. Scholars have even pointed out that some in the Russian political elite have already "made clear their fear that the SCO was becoming a vehicle for Chinese economic penetration of Central Asia and even Russia itself." ${ }^{143}$ As Mankoff points out, "China already accounts for a greater percentage of foreign trade in Kazakhstan, Kyrgyzstan and Tajikistan than does Russia, gradually eroding Moscow's economic and political influence." ${ }^{144}$ Waning Russian influence in these key states of Eurasia is therefore particularly motivating for Russia to increase its diplomatic efforts on these areas. Russia's recent agreements with Kyrgyzstan concerning Russian investments in Kyrgyz infrastructure, debt forgiveness, and military basing rights, highlights this renewed sense of purpose. As a Kommersant source in the Russian government stated, these strategic engagements "build up the significance of partnership with Moscow for Bishkek and strengthen the Russian influence on geopolitics of the entire region." 145 The creation of a Eurasian Union would not only prevent further encroachment of China into Central Asia, but also that of the US. As the basing rights agreement with Kyrgyzstan shows, Russian military bases would be installed at the expense of proposed US bases, thereby

\footnotetext{
${ }^{141}$ Jeffrey Mankoff, "What a Eurasian Union Means for Washington," The National Interest, April 19, 2012, $<$ http://nationalinterest.org/commentary/what-eurasian-union-means-washington-6821?page=1> (Accessed April 23, 2012).

${ }^{142}$ Raffaello Pantucci \& Alexandros Petersen, 'Russia's Eastern Anxieties,"” New York Times, October 17, 2011, $<$ www.nytimes.com/2011/10/18/opinion/18ihtedpantucci18.html?_r=1\&scp=1\&sq=eurasian\%20union\&st=cse> (Accessed October 28, 2011).

${ }^{143}$ Mark N. Katz, "Russia and the Shanghai Cooperation Organization: Moscow's Lonely Road from Bishkek to Dushanbe," Asian Perspective, 32 (3 2008): 185.

${ }^{144}$ Mankoff, "What a Eurasian Union Means for Washington."

145 "Russia, Kyrgyzstan to conclude three significant agreements in fall," Russia Beyond the Headlines, August 23, 2012,

<http://rbth.ru/articles/2012/08/23/russia_kyrgyzstan_to_conclude_three_significant_agreements_in_fall_17595. html> (Accessed August 24, 2012). Emphasis added.
} 
preventing the US from entering its 'near abroad'. Clearly, economic, political, and military incentives - the basis for the Eurasian Union - was also a geopolitical strategy to maintain Russian influence in Central Asia at the expense of competing powers.

Yet, the specter of a rising China is chief among Russia's anxieties. Russia sees increased Chinese presence in Central Asia particularly disconcerting. This concern has manifested itself into Putin's proposal for a Eurasian Union— by offering economic incentives to reintegrate (to some degree) with Russia it will thereby negate any advances made by China in the region. Further, as the Wall Street Journal notes, "From a geopolitical perspective, it is all but certain that Chinese influence in Siberia will grow as Russia's population shrinks, and future Chinese governments may well come to have a proprietary interest in the region." ${ }^{146}$ By creating an alternative to the SCO, Russia hopes to dampen the potential for continued growth of Chinese influence in the region. The increasing presence and power of China in Central Asia provides states in the region an alternative, viable, and powerful leverage point to diminish Russian influence. This classic zero-sum logic is at the heart of Russian foreign policy and demonstrates the geopolitical logic behind this proposed integration project. As the Russian representative to the SCO delicately explained, “. . . one of the difficult but very important tasks for the future will be to find the optimal option for the blending of the SCO into an emerging system of Eurasian integration." 147 The Eurasian Union can thus be understood as a response to growing fears of Chinese encroachment in Central Asia. In this context, such a response is a genuine demonstration of Geopolitical Eurasianism - it illustrates Russia's continued great power ambitions and the underlying geopolitical logic that motivates those aspirations.

A telling example of this occurred at the Valdai International Discussion Club on China. There, a senior Russian defense analyst allayed a Japanese official's concern over Russia's recent purchase of a Mistral warship to be used in the Pacific. He suggested that Japan should not "worry about the likely placement of the Mistral warship in the Russian Far East, since its main function would be to deter China, not fight Japan." 148 Increasingly it would seem that Russian fears of a rising China have been the one of the main catalysts for Russia's most Eurasianist action yet - the potential for economic, political, and military rivalry has finally spurred Russia into focusing more on a region which it has, at times,

\footnotetext{
${ }^{146}$ Michael Auslin, "Russia Fears China, Not Japan,” The Wall Street Journal, March 4, 2011, <http://online.wsj.com/article/SB10001424052748703559604576175660916870214.html> (Accessed December 11, 2011).

${ }^{147}$ Barsky, "Central Asia Under the SCO's 'Impermeable Umbrella,"” 158.

${ }^{148}$ Richard Weitz, "What Russia Fears in Asia," The Diplomat, June 6, 2011, <http://thediplomat.com/2011/06/06/what-russia-fears-in-asia/> (Accessed December 11, 2011).
} 
neglected. In doing so, Russian leaders have embraced a policy of Geopolitical Eurasianism that shifts its foreign policy towards a more nuanced approach to periphery and the West. This shift forces Russia to focus more on its unique geopolitical location which will ultimately foster more engagement towards its neighbors and less towards the West on the whole.

One can see this policy already being implemented. Since retaking office, Putin's first official presidential visits have primarily been to countries in Russia's 'near abroad', especially in Central Asia. Significantly, Putin made the decision not to attend the G8 summit in the United States, a move that has widely been viewed as a conscious snub to the West and NATO over various grievances. ${ }^{149}$ Instead his first extended visit was to China, ahead of an SCO summit. Dmitry Suslov, a defense policy expert based in Moscow noted the importance of this decision as it shows Putin's "personal distrust of the US" and that Russia is "not ready to continue the relationship with the US on the same level that [it] did under Medvedev." "150 Putin's actions reflect a fundamental shift in Russia's strategic priorities. More attention will be paid to its 'near abroad' where Russian interests are better met, and less effort will be made for further collaboration with the West. The Eurasian Union embodies this policy and relatedly the Geopolitical Eurasianist doctrine. With these high profile decisions, Putin has signaled a shift away from engagement with the West and its related failures and towards areas closer in proximity to Russia. These places have historically been areas where Russia has been more successful in exerting its power and influence, a direct contrast with its attempts at integration and collaboration with the West.

The choice of Belarus and Kazakhstan as members of the Eurasian Union demonstrates that Russia is reprioritizing relations with states that they perceive as more open to cooperation than the West. However, the omission of Ukraine is a point of contention for Russia. As Putin implored recently, "We regret greatly that fraternal Ukraine has not joined us in this process. The most independent and objective expert analyses show that Ukraine would indisputably stand to benefit from joining this group . . . It would be advantageous for all in economic and social terms, for Ukraine itself, and for the entire group." ${ }^{151}$ This statement is demonstrative of future Russian foreign policy as it relates to the Eurasian Union. Although

\footnotetext{
${ }^{149}$ John Chan, "Putin's visit to China signals sharpening global tensions," Centre for Research on Globalization (CRG), June 10, 2012, <http://www.globalresearch.ca/putin-s-visit-to-china-signals-sharpening-globaltensions/> (Accessed June 20, 2012).

${ }^{150}$ Fred Weir, "Russians perplexed by Putin's snub of G8. Is it because of protests? Obama?" CS Monitor, May 14, 2012, <http://www.csmonitor.com/World/Europe/2012/0514/Russians-perplexed-by-Putin-s-snub-of-G8.-Isit-because-of-protests-Obama> (Accessed July 27, 2012).

${ }^{151}$ Putin, "Russia's Foreign Policy Has Always Been Independent and It Will Remain So," 5.
} 
the integration project has started out small, Russia will seek to expand its scope over time in an effort to broaden Russia's influence.

The Eurasian Union is therefore a useful vehicle for pursuing Russia's doctrine of Geopolitical Eurasianism. First, it allows Russia to establish itself as power pole in an emerging multipolar system. The integration project increases Russia's economic and political clout in a strategically important region of the world. Second, it does this by rejecting Western models of development and integration in favor of a distinctly 'Eurasian' alternative which embraces Russia's multiethnic composition. Echoing the 'third way' Putin declared that, "Russia's foreign policy has always been independent and it will remain so."152 Third, the proposed Eurasian Union demonstrates a clear geopolitical logic. It is an obvious hedge against outside power encroachment into what Russia sees as its 'privileged sphere of influence' and also a reassertion of Russian control over these areas. The Eurasian Union is therefore the culminating event in Russian foreign policy's incremental process of adopting the Geopolitical Eurasianist doctrine. It embodies each of the doctrine's core principles to an extent that has not been seen previously. This process, beginning in 2000, has had various milestones as illustrated in this chapter. Each one has demonstrated the adoption of this doctrine to ever increasing degrees. Putin's grand proposal is simply the most overt expression of a process that seems likely to continue.

\section{Conclusion}

It has become readily apparent over the course of this study that Eurasianism is, if anything, an idea that is varied and has evolved over time. This multidimensional character has been a strong historical linkage over the course of its three main formative periods. The doctrine of Eurasianism has been variously interpreted by many groups and individuals and draws upon an array of disciplines including history, politics, geography, economics, philosophy, and theology. The enormous scope of Eurasianism is perhaps what makes it so hard to comprehensively define throughout its history. However, major threads of continuity have been established in the previous chapters of this study. An overarching theme, especially within Eurasianism's most recent variant identified in this work, has developed in a highly reactionary fashion, perceiving a world that is increasingly at odds with Russian interests. Since Vladimir Putin's rise to the Russian Presidency in 2000, the Geopolitical Eurasianist doctrine has increasingly guided Russian foreign policy. This process was incremental, the

\footnotetext{
${ }^{152}$ Ibid, 4.
} 
result of a series of external factors and internal responses which was traced in the analysis chapter of this study. The doctrine itself was thus the result of this slow progression, by which Russia increasingly felt isolated in an international system they saw as titled towards the West and the United States in particular. To better address these concerns, and also to more efficiently promote Russian interests abroad, Russian foreign policy has shifted towards this doctrine to meet these needs.

To this end, the Geopolitical Eurasianist doctrine contains three basic principles which have increasingly guided Russian foreign policy since 2000. First, the doctrine rejects Western socioeconomic and political modes of development in favor of a distinctly nonWestern alternative. This is most evident in the Russian leadership's promotion of the idea of 'sovereign democracy' and its proposal to create a Eurasian Union. In particular, the creation and promotion of international institutions which are more easily controlled by Moscow is an overarching priority. Second, this doctrine encourages a reassertion of Russia's great power status. It rejects an international system it sees as too dominated by one or a few powers and instead seeks to promote the idea of multipolarity with Russia as one of the system's leading powers. The Russo-Georgian War of 2008 best encapsulates this principle. Third, and most importantly, this Eurasianist doctrine emphasizes an underlying geopolitical logic which informs the creation and implementation of Russian foreign policy. This logic is a way of viewing the world as distinctive areas of geographic, economic, and strategic importance all situated in a competitive, zero-sum game environment. Moreover, it emphasizes Russia's strategically valuable location in Eurasia as a great source of strength. The Russian leadership's continued usage of the terms 'near abroad' and 'privileged spheres of influence' most directly illustrate this geopolitical foundation. Russia's anxiety over a rising China also demonstrates the salience of this tenet to the formulation and implementation of Russia's foreign policy.

The adoption of the Geopolitical Doctrine was also borne out of a need for a better articulation for where Russia sees itself in the international system. The chaotic and tumultuous period that came to characterize the 1990s under Yeltsin pointedly demonstrated this need to the Russian leadership once Putin came to power. It was also during the 1990s and into Putin's first term that Russia began to perceive the West, especially the United States, in a more adversarial fashion. Failed attempts at collaboration or compromise on key strategic issues between Russia and the West resulted in alienation of Russia from the international system. While each party was at fault for this failure, it nonetheless encouraged Russia's leadership to seek an alternative doctrine to guide its foreign policy decision-making. 
Geopolitical Eurasianism, with its unique and wide array of policy options, was an attractive alternative that Russia has subsequently embraced. Yet, it would be wrong to say that because of this Russian foreign policy has become overtly anti-Western or anti-American. Instead it is wholly non-Western, embracing a foreign policy approach that is distinctly Russian in nature and therefore independent in its own right.

The trajectory of Russia's foreign policy will most likely stay on a Geopolitical Eurasianist course for the foreseeable future. The personalized system of authority in Russia assures this. It is highly unlikely that Vladimir Putin will leave the presidency in the near to medium-term, especially in light of domestic events over the past year. Putin's unusually critical comments regarding his protégé Medvedev, coupled with increasingly authoritarian legislation this year, has helped solidify Putin's grip on power. It is clear that Putin and a close circle of advisers are sympathetic to this Eurasianist doctrine. As a consequence, as long as Putin and his coterie stay in power, the Geopolitical Eurasianist doctrine will remain the most salient factor in the formulation and implementation of Russian foreign policy.

Eurasianism, particularly this Geopolitical variant, is thus an important doctrine that warrants further academic inquiry. It will remain the dominant paradigm for Russian diplomacy for many years to come and is thus an invaluable tool for understanding Russian actions over the past decade and well into the future. 


\section{Bibliography}

\section{Primary Sources:}

Barsky, Kirill. "Central Asia Under the SCO's 'Impermeable Umbrella.'” Mezhdunarodnaya Zhizn [International Affairs] 4 (2012): 151-163.

Dugin, Aleksandr. "Catechism of member of the Eurasian Youth Union." $<$ http://www.rossia3.ru/katehizis.html> (Accessed May 13 ${ }^{\text {th }}, 2012$ ).

Dugin, Aleksandr. "Main Principles of Eurasist Policy." Trans. Martino Conserva. 2001. $<$ http://www.evrazia.org/modules.php?name=News\&file=article \&sid=421> (Accessed May 10, 2012).

Dugin, Aleksandr. "We- The Party of the National Idea" (Speech at Political Conference, All Russian Political Public Movement, March 1, 2002). <http://www.evrazia.org/modules.php?name=News\&file=article\&sid=736> (Accessed May 12, 2012).

Lavrov, Sergey. "Speech by Russian Minister of Foreign Affairs Sergey Lavrov at the Foreign Ministry's MGIMO University on the Occasion of the New Academic Year" (MGIMO University, Moscow, September 1, 2008). <http://www.mid.ru/bdomp/brp_4.nsf/e78a48070f128a7b43256999005bcbb3/d2ca87d 862a0db6dc32574b9001d9be5!OpenDocument> (Accessed August 14, 2012).

Medvedev, Dmitry. "The Foreign Policy Concept of the Russian Federation." Ministry of Foreign Affairs of the Russian Federation (July 12, 2008).

$<$ http://archive.kremlin.ru/eng/text/docs/2008/07/204750.shtml> (Accessed May 28, 2012).

Medvedev, Dmitry. "Interview given by Dmitry Medvedev to Television Channels." Channel One, Rossia, and NTV (August 31, 2008).

<http://archive.kremlin.ru/eng/text/speeches/2008/08/31/1850_type82912type82916_2 06003.shtml> (Accessed August 12, 2012).

Medvedev, Dmitry. "National Security Strategy of the Russian Federation to 2020." Trans. Alisa Lockwood. Office of the President (May 12, 2009). < http://rustrans.wikidot.com/russia-s-national-security-strategy-to-2020> (Accessed May 12, 2012).

Medvedev, Dmitry. "Statement on the Situation in South Ossetia." The Kremlin (August 8, 2008). <http://archive.kremlin.ru/eng/speeches/2008/08/08/1553_type82912type82913_2050 32.shtml> (Accessed August 20, 2012).

North Atlantic Treaty Organization. "Founding Act on Mutual Relations, Cooperation and Security between NATO and the Russian Federation.” Paris, France, May 27, 1997. <http://www.nato.int/cps/en/natolive/official_texts_25468.htm> (Accessed June 12, 2012). 
Putin, Vladimir. "Annual Address to the Federal Assembly of the Russian Federation" (The Kremlin, Moscow, April 25, 2005).

$<$ http://archive.kremlin.ru/eng/speeches/2005/04/25/2031_type70029type82912_8708

6.sht> (Accessed June 15, 2012).

Putin, Vladimir. "The Foreign Policy Concept of the Russian Federation." Ministry of Foreign Affairs of the Russian Federation (June 28, 2000).

<http://www.fas.org/nuke/guide/russia/doctrine/econcept.htm> (Accessed May 26, 2012).

Putin, Vladimir. "Interview with Radio Slovensko and the Slovakian Television Channel STV.” Radio Slovensko (February 22, 2005).

<http://archive.kremlin.ru/eng/speeches/2005/02/22/2038_type82916_84445.shtml> (Accessed May 15, 2012).

Putin, Vladimir. "National Security Concept of the Russian Federation." Ministry of Foreign Affairs of the Russian Federation (January 10, 2000). <http://www.mid.ru/bdomp/nsosndoc.nsf/1e5f0de28fe 77fdcc32575d900298676/36aba64ac09f737fc32575d9002bbf3 1 !OpenDocument> (Accessed May 28, 2012).

Putin, Vladimir. "A new integration project for Eurasia: The future in the making." Izvestia, October 4, 2011. <http://rusemb.org.uk/press/246> (Accessed October 5, 2011).

Putin, Vladimir. "Russia's Foreign Policy Has Always Been Independent and It Will Remain So." Mezhdunarodnaya Zhizn [International Affairs] 4 (2012): 1-8.

Putin, Vladimir. "Speech and the Following Discussion at the Munich Conference on Security Policy" (Munich, Germany, February 10, 2007).

<http://archive.kremlin.ru/eng/speeches/2007/02/10/0138_type82912type82914type82 917type84779_118123.shtml> (Accessed June 24, 2012).

Putin, Vladimir. "Statement on Iraq at Kremlin Meeting." The Kremlin (March 20, 2003). <http://archive.kremlin.ru/eng/text/speeches/2003/03/20/0000_type82912type82913_4 4225.shtml> (Accessed June 10, 2012).

Vernadsky, George. A History of Russia. $5^{\text {th }}$ ed. New Haven: Yale University Press, 1961.

\section{Secondary Sources:}

Aizlewood, Robin. "Revisiting Russian Identity in Russian Thought: From Chaadaev to the Early Twentieth Century." The Slavonic and East European Review 78 (January 2000): 20-43.

Anable, David. "The Role of Georgia's Media—and Western Aid—in the Rose Revolution." Joan Shorenstein Center on the Press, Politics and Public Policy (Fall 2005). <http://shorensteincenter.org/wp-content/uploads/2012/03/2006_03_anable.pdf> (Accessed June 10, 2012). 
Asmus, Ronald D. A Little War that Shook the World: Georgia, Russia, and the Future of the West. New York, NY: Palgrave Macmillan, 2010.

Averre, Derek. "From Pristina to Tskhinvali: the legacy of Operation Allied Force in Russia's relations with the West." International Affairs 85 (2009): 575-591.

British Broadcasting Company. Putin, Russia, and the West. Series I-IV (London: BBC Two, 2012).

Christoff, Peter. Introduction to Nineteenth-Century Russian Slavophilism. 4 vols. Boulder, CO: Westview Press, 1961-1991.

Clover, Charles. "Dreams of the Eurasian Heartland: The Reemergence of Geopolitics." Foreign Affairs 78 (March - April 1999): 9-13.

Copilaş, Emanuel. "Cultural Ideal or Geopolitical Project? Eurasianism's Paradoxes.” Strategic Impact (3 2009): 65-80.

Cornell, Svante E. "Pipeline Power: The War in Georgia and the Future of the Caucasian Energy Corridor." Georgetown Journal of International Affairs 10 (Winter 2009): 131-39.

Dobieszewski, Janusz. " Pëtr Chaadaev and the Rise of Modern Russian Philosophy.” Studies in East European Thought 54 (March 2002): 25-46.

Dunlop, John. “Aleksandr Dugin's 'neo-Eurasianist' Textbook and Dmitrii Trenin's Ambivalent Response.” Harvard Ukrainian Studies 25 (Spring 2001): 91-127.

Fadner, Frank. Seventy years of Pan-Slavism in Russia: Karazin to Danilevskil: 1800-1870. Washington, D.C.: Georgetown University Press, 1962.

Glebov, Serguei. "The Challenge of the Modern: The Eurasianist Ideology and Movement, 1920-29.” PhD diss., The State University of New Jersey, Rutgers, 2004.

Heller, Peggy. "The Russian Dawn: How Russia Contributed to the Emergence of 'the West' as a Concept." In The Struggle for the West: A Divided and Contested Legacy, edited by Christopher Browner \& Marko Lehti, 33-52. London, UK: Routledge Press, 2009.

Ingram, Alan. "Alexander Dugin: geopolitics and neo-fascism in post-Soviet Russia." Political Geography 20 (2001): 1029-1051.

Katz, Mark N. "Russia and the Shanghai Cooperation Organization: Moscow's Lonely Road from Bishkek to Dushanbe.” Asian Perspective, 32 (3 2008): 183-187.

Kucharzewski, Jan. The Origins of Modern Russia. Trenton, NJ: Polish Institute of Arts and Sciences in America, 1948.

Laqueur, Walter. Black Hundred: The Rise of the Extreme Right in Russia. New York, NY: Harper Collins Publishers, 1993. 
Laruelle, Marlène. “(Neo-) Eurasianists and Politics: 'Penetration' of State Structures and Indifference to Public Opinion?" Russian Politics and Law 47 (January - February 2009): 90-101.

Laruelle, Marlène. "Histoire d'une usurpation intellectuelle : L. N. Gumilev, 'le dernier des eurasistes' ? Analyse des oppositions entre L. N. Gumilev et P. N. Savickij [History of intellectual theft: L. N. Gumilev, 'the last of the Eurasianists'? Analysis of contrasts between L. N. Gumilev and P. N. Savickij]." Revue des études slaves 73 (2001): 449459.

Laruelle, Marlène. "The Orient in Russian Thought at the Turn of the Century." In Russia Between East and West: Scholarly Debates on Eurasianism, edited by Dimitry Shlapentokh, 9-37. Leiden, Netherlands: Brill Publishing, 2007.

Laruelle, Marlène. Russian Eurasianism: An Ideology of an Empire. Trans. Mischa Gabowitsch. Washington, D.C.: Woodrow Wilson Center Press, 2008.

Liverant, Yigal. “The Prophet of the New Russian Empire.” Azure 35 (Winter 2009): 50-83.

Livezeanu, Irina. "Defining Russia at the Margins.” Russian Review 54 (October 1995): 495499.

Mackinder, Halford J. "The Geographical Pivot of History.” The Geographical Journal 23 (April 1904): 421-437.

Mankoff, Jeffrey. Russian Foreign Policy: The Return to Great Power Politics. Plymouth, UK: Rowman \& Littlefield Publishers, 2009.

Mankoff, Jeffrey. "What a Eurasian Union Means for Washington." The National Interest, April 19, 2012. <http://nationalinterest.org/commentary/what-eurasian-union-meanswashington-6821?page $=1>($ Accessed April 23, 2012).

Mazurek, Sławomir. "Russian Eurasianism: Historiosophy and Ideology.” Trans. Guy R. Torr. Studies in East European Thought 54 (March 2002): 105-123.

McDermott, Roger. "Moscow Fears Shift in Central Asia’s Strategic Balance Post-2014." Eurasia Daily Monitor 9 (June 22, 2012), $<$ http://www.jamestown.org/programs/edm/single/?tx_ttnews[tt_news]=39523\&cHash =992b418ce8d96460bc98ad6b6ea49237> (Accessed June 23, 2012).

Paradowski, Ryszard, Liliana Wysocka, and Douglas Morren. "The Eurasian Idea and Leo Gumilëv's Scientific Ideology.” Canadian Slavonic Papers 41 (March 1999): 19-32.

Rabow-Edling, Susanna. Slavophile Thought and the Politics of Cultural Nationalism. Albany, NY: State University of New York Press, 2006.

Riasanovsky, Nicholas. Russia and the West in the Teaching of the Slavophiles. Cambridge, MA: Harvard University Press, 1952. 
Riasanovsky, Nicholas V.. "Prince N. S. Trubetskoy's 'Europe and Mankind.'” Jahrbücher für Geschichte Osteuropas 12 (July 1964): 207-220.

Schmidt, Matthew. “'Is Putin Pursuing a Policy of Eurasianism?', Demokratizatsiya, 13 (Winter 2005): 87-99.

Sengupta, Anita. Heartlands of Eurasia: The Geopolitics of Political Space. Lanham, MD: Lexington Books, 2009.

Shlapentokh, Dmitry. "Reassessment of the Relationship: Polish History and the Polish Question in the Imperial Duma." East European Quarterly 33 (Spring 1999): 115-135.

Thom, Françoise. "Eurasianism: A New Russian Foreign Policy?" Uncaptive Minds 7 (Summer 1994): 65-77.

U.S. Congress. House. Committee on International Relations. Celeste A. Wallander Testimony for Russia's Policies toward the Axis of Evil: Money and Geopolitics in Iraq and Iran. $108^{\text {th }}$ Cong., $1^{\text {st }}$ sess., February 26, 2003.

<http://www.globalsecurity.org/military/library/congress/2003_hr/wall0226.htm> (Accessed June 12, 2012).

VCIOM. "Siberia and the Far East: 'Forgotten Land' or 'Engine of Development'?" $<$ http://wciom.com/index.php?id=61\&uid=682> (Accessed July 12, 2012).

Walicki, Andrzej. A History of Russian Thought from the Enlightenment to Marxism. Stanford, CA: Stanford University Press, 1979. 